This PDF is a selection from a published volume from the National Bureau of Economic Research

Volume Title: Education, Skills, and Technical Change: Implications for Future US GDP Growth

Volume Authors/Editors: Charles R. Hulten and Valerie A. Ramey, editors

Volume Publisher: University of Chicago Press

Volume ISBNs: 978-0-226-56780-8 (cloth); 978-0-226-56794-5 (electronic); 0-226-56780-X (cloth)

Volume URL: http://www.nber.org/books/hult-12

Conference Date: October 16-17, 2015

Publication Date: December 2018

Chapter Title: Educational Attainment and the Revival of US Economic Growth

Chapter Author(s): Dale W. Jorgenson, Mun S. Ho, Jon D. Samuels

Chapter URL: http://www.nber.org/chapters/c13695

Chapter pages in book: (p. $23-60$ ) 


\title{
Educational Attainment and the Revival of US Economic Growth
}

\author{
Dale W. Jorgenson, Mun S. Ho, and Jon D. Samuels
}

\subsection{Introduction}

Labor-quality growth captures the upgrading of the labor force through higher educational attainment and greater experience. While much attention has been devoted to the aging of the labor force, the implications of the coming plateau in educational attainment have been neglected. ${ }^{1}$ Average levels of educational attainment remain high for people entering the labor force, but will no longer increase. Rising average educational attainment will gradually disappear as a source of US economic growth.

We define the employment rate as the number employed as a proportion of the corresponding population. We find that the employment rate for each age-gender category increases with educational attainment. The investment boom of 1995-2000 drew many younger and less educated workers into employment. After attaining a peak in 2000, the employment rates for these workers declined during the recovery of 2000-2007 and dropped further during the Great Recession of 2007-2009. The employment rates for the highly educated groups also fell during the Great Recession, but by 2015 they had recovered more than the employment rates of the less educated groups.

Dale W. Jorgenson is the Samuel W. Morris University Professor at Harvard University. Mun S. Ho is a visiting scholar at Resources for the Future. Jon D. Samuels is a research economist at the Bureau of Economic Analysis.

The views expressed in this chapter are solely those of the authors and not necessarily those of the US Bureau of Economic Analysis or the US Department of Commerce. We are grateful to Douglas Elmendorf and the editors, Charles Hulten and Valerie Ramey, for their comments on an earlier version of our manuscript. We are also grateful to the BEA for sharing their labor-input estimates. For acknowledgments, sources of research support, and disclosure of the authors' material financial relationships, if any, please see http://www.nber.org/chapters /c13695.ack.

1. See Aaronson, $\mathrm{Hu}$, et al. (2014) and Aaronson, Cajner, et al. (2014). 
In order to assess the prospects for US economic growth in more detail, we present a new data set on US output and productivity growth by industry for the postwar period, 1947-2014. This includes outputs for the sixty-five industries represented in the US National Income and Product Accounts (NIPAs). The new data set also includes inputs of capital (K), labor (L), energy (E), materials (M), and services (S), hence the acronym KLEMS. The rate of growth of productivity is the key indicator of innovation, where productivity is defined as the ratio of output to input for each industry.

A distinctive feature of our new US data set is detailed information on employment for the US labor force. This covers the period 1947-2014 and enables us to characterize the relationship between employment and the age, gender, and educational attainment of workers over more than six decades. Since the revival of US economic growth depends critically on the recovery of US employment rates, we utilize this new information on employment in assessing the prospects for a US growth revival.

Are the lower employment rates of the less educated workers a "new normal" for the US labor force that will persist for some time? Or, will the continuing economic recovery enable these workers to resume the higher employment rates that preceded the Great Recession? The answers to these questions are critical for the future growth of the US economy. In order to assess the prospects for recovery of employment as a potential source for the revival in US economic growth, we account for the employment rate of each age-gender-education group.

We build on the work of Jorgenson, Ho, and Stiroh (2005), who presented an industry-level data set for outputs, inputs, and productivity for the US economy for the period 1977-2000. For the earlier period 1947-1977, our new data set captures the postwar recovery of the US economy, ending with the energy crisis of 1973. For the recent period 2000-2014, our new data set highlights the slowdown in productivity growth after 2007, the fall in investment during the Great Recession of 2007-2009, and the slow recovery since 2009.

Paul Schreyer's (2001) Organisation for Economic Co-operation and Development (OECD) manual, Measuring Productivity, established international standards for economy-wide and industry-level productivity measurement. These standards are based on the production account for the US economy presented by Jorgenson, Gollop, and Fraumeni (1987) in their book, Productivity and U.S. Economic Growth. This was recommended by the Statistical Working Party of the OECD Industry Committee (2001). The Statistical Working Party was chaired by Edwin Dean, former Associate Commissioner for Productivity of the US Bureau of Labor Statistics (BLS).

We present a prototype production account within the framework of the US national accounts. This production account includes newly available estimates for the growth of outputs and intermediate inputs for the period 1998-2014 from the Bureau of Economic Analysis (BEA). We combine 
these estimates with data from the production account for the United States for the period 1947-2012 that we presented in Jorgenson, Ho, and Samuels (2016). We aggregate industries by means of the production possibility frontier employed by Jorgenson, Ho, and Stiroh (2005) and Jorgenson and Schreyer (2013). This links industry-level data on US growth and productivity to the economy-wide data from the US national accounts presented by Harper et al. (2009).

The first application of our new industry-level data set on outputs, inputs, and productivity is to analyze the sources of postwar US economic growth. We divide the Postwar Period, 1947-2014, into three subperiods - the Postwar Recovery, 1947-1973; the Long Slump following the 1973 energy crisis, 1973-1995; and the recent period of Growth and Recession, 1995-2014. We provide more detail on the period of Growth and Recession by considering the subperiods of the Investment Boom, 1995-2000; the Jobless Recovery, 2000-2007; and the Great Recession, 2007-2014.

We show that nearly 80 percent of US economic growth since 1947 is due to the growth of capital and labor inputs. This reflects the expansion and upgrading of the labor force and investments in plant equipment, and intangible assets like research and development and software. Only 20 percent of US growth is due to growth in productivity, output per unit of input, which captures innovation. Of course, economic growth involves both accumulation of capital and labor inputs and the introduction of new technologies, but factor accumulation greatly predominates as a source of US economic growth.

Our finding on the relative unimportance of innovation is the reverse of the well-known conclusions of Robert M. Solow (1957) and Simon Kuznets (1971). Solow and Kuznets found that innovation, represented by productivity growth, accounts for 80 percent of US economic growth, while accumulation of capital and labor inputs, the primary factors of production, accounts for only 20 percent. The sharp reversal of this conclusion is the most important empirical finding from several decades of research on productivity growth summarized by Jorgenson (2009) and Jorgenson, Fukao, and Timmer (2016). ${ }^{2}$

The reversal of the key empirical findings from the research of Solow (1957) and Kuznets (1971) can be traced to the critically important changes in methodology introduced by Jorgenson, Gollop, and Fraumeni (1987) and Jorgenson, Ho, and Stiroh (2005). These changes are summarized by Schreyer's $(2001,2009)$ OECD manuals. The new methodology for measuring productivity has had an enormous impact on the practice of pro-

2. An industry-level production account for the United States for the period 1947-2012 is presented in our paper, Jorgenson, Ho, and Samuels (2016). The official industry-level production account for the period 1998-2012 is presented by Rosenthal et al. (2016) and in Jorgenson, Fukao, and Timmer (2016, chapter 11, 377-428). 
ductivity measurement. More than forty countries have employed the new methodology for productivity measurement and more than a dozen of these countries, including the United States, use this methodology to generate official estimates of productivity growth within the framework of the national accounts.

The predominant role of growth in capital and labor inputs in US economic growth is crucial for the formulation of economic policy. During the prolonged recovery from the Great Recession of 2007-2009, economic policy must focus on reviving investment and reestablishing the prerecession employment rates of the labor force. Policies for stimulating innovation would have a very limited impact.

The second application of our new data set is to project the future growth of the US economy. For this purpose we employ the methodology of Jorgenson, Ho, and Stiroh (2008). ${ }^{3}$ We aggregate over industries to obtain data for the US economy as a whole. We project the future growth of labor input and productivity. We then determine the future growth of output consistent with the assumption that output and capital must grow at the same rate. This assumption eliminates the transitional dynamics associated with the accumulation of capital. We discuss the methodology for projecting future US economic growth in more detail in the appendix to this chapter.

We first consider the growth of labor input as a determinant of US economic growth. We project the size of the labor force from the growth and composition of the population. We then project the future growth of labor quality from the educational attainment of age cohorts of the population as they enter the labor force and the increase in experience as these cohorts age. Finally, we account for the employment rates for each age-gender-education category of the labor force, projecting them from 2014 levels.

We next consider productivity growth as a determinant of future US economic growth. To characterize the uncertainty that characterizes future trends, we construct a Base Case projection based on productivity growth for the period of Growth and Recession, 1995-2014. We then develop a Low Growth Case that also incorporates productivity trends for 1973-2014, including the Long Slump of 1973-1995, as well as the period 1995-2014. Finally, we present a High Growth Case based on productivity growth during the Investment Boom of 1995-2000 and the Jobless Recovery of 2000-2007. This excludes the Recession and Recovery of 2007-2014. We find that US economic growth will continue to recover from the Great Recession of 2007-2009 through the resumption of growth in productivity and labor input. However, the growth rate of the US economy in the next decade will depend critically on the revival of employment rates that prevailed before the Great Recession. We compare our results with the

3. Jorgenson and $\mathrm{Vu}$ (2017) employ this methodology to project the growth of the United States and the world economy. 
projections by the Congressional Budget Office (2016) and John Fernald $(2014,2016)$. The final section of the chapter presents our conclusions.

\subsection{A Prototype Industry-Level Production Account for the United States, 1947-2014}

Our first objective is to construct a new data set for growth and productivity of the US economy at the industry level. This is greatly facilitated by the progress of the Bureau of Economic Analysis (BEA) in developing a system of industry accounts within the framework of the US National Income and Product Accounts. The BEA has successfully integrated three separate industry programs - benchmark input-output tables, released every five years; annual input-output tables; and annual estimates of gross domestic product by industry. The BEA's system of industry accounts is described by Mayerhauser and Strassner (2010).

McCulla, Holdren, and Smith (2013) summarize the 2013 benchmark revision of the NIPAs. A particularly significant innovation is the addition of intellectual property products such as research and development and entertainment, artistic, and literary originals. Intellectual property products are treated symmetrically with other capital expenditures. Investments in intellectual property are included in the gross domestic product (GDP), and the capital services generated by these investments are included in the national income.

Kim, Strassner, and Wasshausen (2014) describe the 2014 benchmark revision of BEA's industry accounts. These accounts include annual inputoutput tables and gross domestic product by industry and cover the period 1997-2012. The BEA's industry data are consistent with the 2013 benchmark revision of the NIPAs and the benchmark input-output table for 2007. The industry accounts and the annual input-output tables have been updated to 2013 and 2014 by BEA.

Lyndaker et al. (2016) have extended BEA's estimates of output and intermediate inputs to the period 1947-1996. This extension incorporates earlier benchmark input-output tables for the United States, including the first benchmark table for 1947. The BEA has linked these benchmark inputoutput tables to the annual input-output tables and industry accounts for 1997-2014. The BEA industry data are available for forty-six industries for 1947-1962, and sixty-five industries for 1963-2014. The BEA's historical data set includes estimates of output and intermediate input in current and constant prices. We incorporate these estimates into our prototype industrylevel production account. ${ }^{4}$

4. For the period before 1998, BEA uses the industry, commodity, and import prices developed in Jorgenson, Ho, and Samuels (2016) to estimate constant-price industry output and intermediate input. For the 1963-2014 period, we use the BEA estimates in current and constant prices. For the 1947-1962 period, we scale the sixty-five-sector estimates developed by Jorgenson, Ho, and Samuels (2016) to the forty-six industries published by the BEA. 
The BEA has prepared estimates of capital and labor inputs for the period 1998-2014. Our labor-input estimates are taken from Jorgenson, Ho, and Samuels (2016) for 1947-2012. We extrapolate these estimates to 2014, using the version of our labor data set maintained by BEA. This labor data set is used to generate an integrated industry-level production account beginning in 1998 by Steven Rosenthal and Lisa Usher of BLS and Matthew Russell, Samuels, and Strassner of BEA (2016).

Similarly, our estimates of capital input for 1947-2012 are taken from Jorgenson, Ho, and Samuels (2016) and updated to 2014, using capital input estimates in the BEA-BLS integrated industry-level production account. Combining the estimates of labor and capital inputs with estimates of output and intermediate inputs, we obtain an industry-level production account for the United States. This prototype production account covers the period of 1947-2014 in current and constant prices for all sixty-five industries included in the US national accounts. Jorgenson and Schreyer (2013) show how to integrate our prototype industry-level production account into the United Nations'(2009) System of National Accounts 2008.

Our new KLEMS-type data set for the United States is the culmination of our previous research on industry-level outputs, inputs, and productivity for the postwar period. This data set is consistent with BEA's industry accounts and annual input-output tables for 1947-2014 and provides greater industry detail for 1947-1962. The BEA/BLS integrated industry-level production account for 1998-2014, released on January 13, 2017, uses similar methodology. However, our industry-level production account covers the entire postwar period, beginning in 1947.

\subsubsection{Changing Structure of Capital Input}

Swiftly falling information technology (IT) prices have provided powerful economic incentives for the rapid diffusion of IT through investment in hardware and software. A substantial acceleration in the IT price decline occurred in 1995, triggered by a much sharper acceleration in the price decline for semiconductors. The IT price decline after 1995 signaled even faster innovation in the main IT-producing industries - semiconductors, computers, communications equipment, and software — and ignited a boom in IT investment. Figure 1.1 presents price indices for 1973-2014 for asset categories included in our measures of capital input - equipment, computers, software, research and development, artistic originals, and residential structures.

The price of an asset is transformed into the price of the corresponding capital input by multiplying the asset price by the cost of capital introduced by Jorgenson (1963). The cost of capital includes the nominal rate of return, the asset-specific rate of depreciation, and the rate of capital loss due to declining prices. The distinctive characteristics of IT prices - high rates of price decline and rates of depreciation - imply that cost of capital for the 


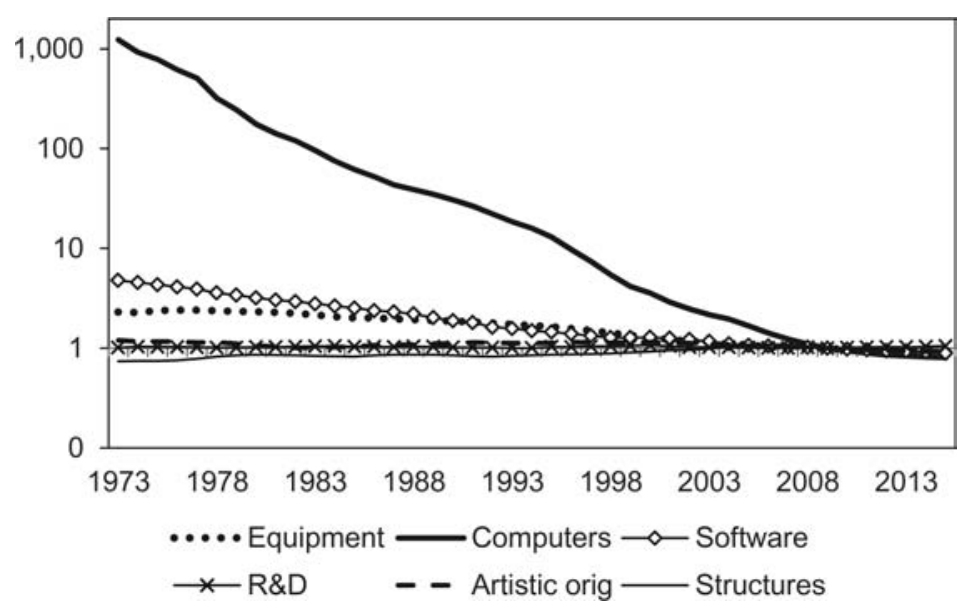

Fig. 1.1 Price of investment relative to GDP deflator (log scale)

price of IT capital input is very high, relative to the cost of capital for the price of non-IT capital input.

Schreyer's (2009) OECD manual provides detailed recommendations for the construction of prices and quantities of capital services. Incorporation of data on labor and capital inputs in constant prices into the national accounts is described in the 2008 System of National Accounts (United Nations 2009, chapters 19 and 20). In chapter 20 of 2008 SNA, estimates of capital services are described as follows: "By associating these estimates with the standard breakdown of value added, the contribution of labor and capital to production can be portrayed in a form ready for use in the analysis of productivity in a way entirely consistent with the accounts of the System" (United Nations 2009, 415).

To capture the impact of the rapid decline in IT equipment prices and the high depreciation rates for IT equipment, we distinguish between the flow of capital services and the stock of capital. Capital quality is defined as the ratio of the flow of capital services to capital stock. Figure 1.2 gives the share of IT in the value of total capital stock, the share of IT capital services in total capital input, and the share of IT services in total output. The IT stock share rose from 1960 to 1995 - on the eve of the IT boom-and reached a high in 2001 after the dot-com bubble. This share fell during the Jobless Recovery with the plunge in IT investment. The share of the IT service flow in the value of total capital input is much higher than the IT share in total capital stock. This reflects the rapid decline in IT prices and the high depreciation rates of IT equipment that enter the formula for the cost of capital associated with the IT service flow. The share of the IT service flow was fairly stable during the period 1960-1980 and then began to rise, reaching a peak 


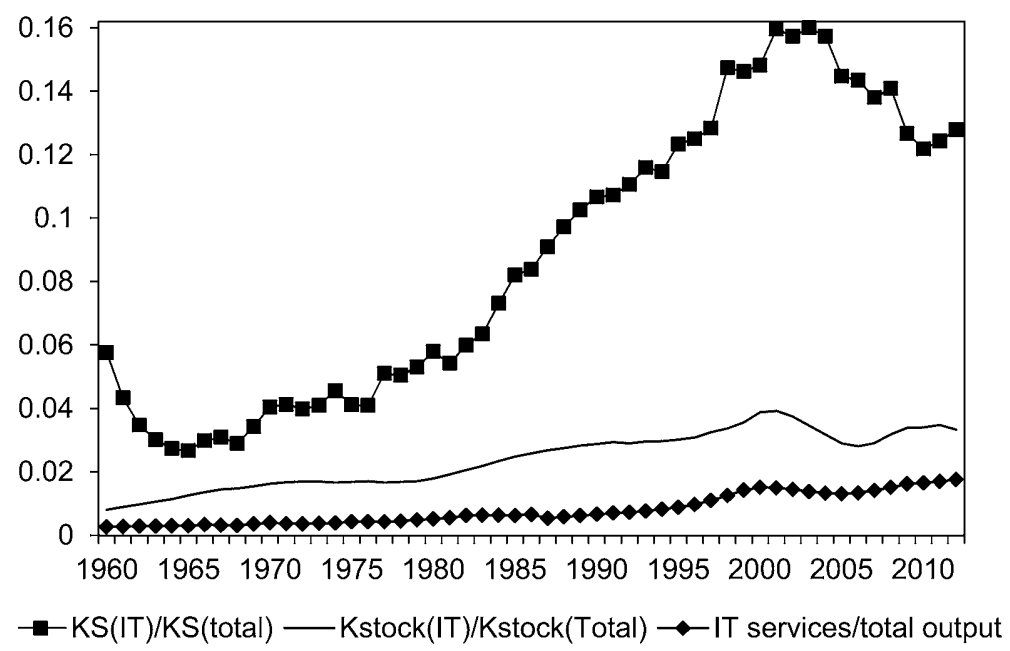

Fig. 1.2 Shares of IT stock, IT capital services, and IT service output in total economy

Note: IT services $=($ information and data processing, computer system design $)$.

in 2000. The IT service flow then declined and ended with a sharp plunge during the Great Recession.

The IT service industries, information and data processing, and computer system design have shown persistent growth. The share of the output of these two industries in the value of the GDP, shown in figure 1.2, declined slightly from 2000 to 2005 and then continued to rise, reaching a high in 2014. This reflects the displacement of IT hardware and software by the growth of IT services like cloud computing. Investment in intellectual property (IP) products since 1973 is shown as a proportion of the GDP in figure 1.3. This proportion grew during the Investment Boom of 1995-2000 and has declined only slightly since the peak around 2000. Investment in research and development also peaked around 2000, but has remained close to this level through the Great Recession.

\subsubsection{Changing Structure of Labor Input}

Our measure of labor input recognizes differences in labor compensation for workers of different ages, educational attainment, and gender, as described by Jorgenson, Ho, and Stiroh (2005, chapter 6). The rate of laborquality growth is the difference between the growth rate of labor input and the growth rate of hours worked. For example, a shift in the composition of labor input toward more highly educated workers, who receive higher wages, contributes to the growth of labor quality. Figure 1.4 shows the decomposition of changes in labor quality into age, education, and gender components.

During the Postwar Recovery of 1947-1973, the massive entry of young, 


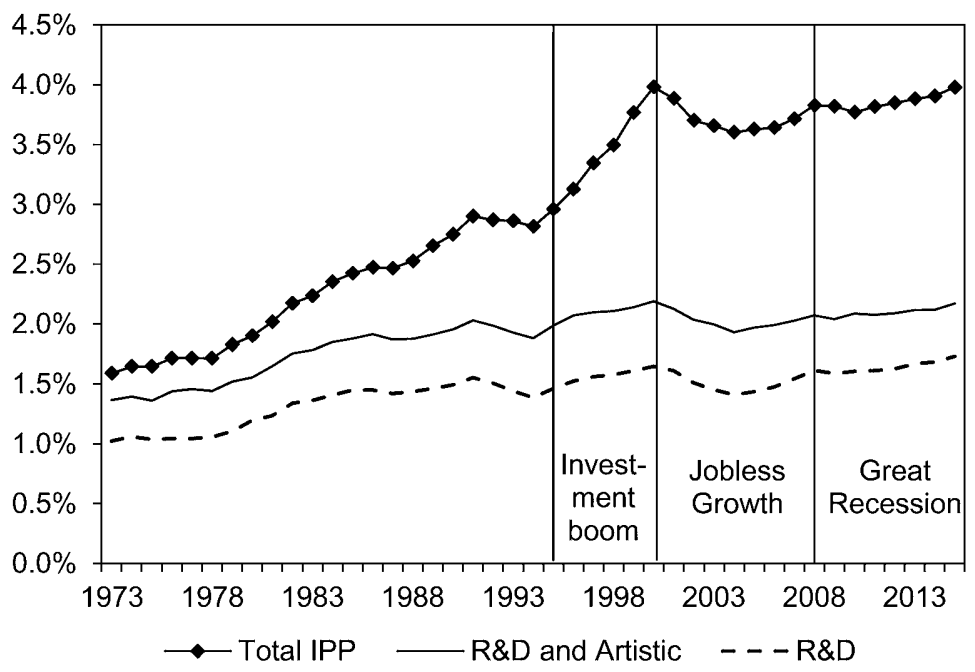

Fig. 1.3 Share of intellectual property investment in GDP (percentage)

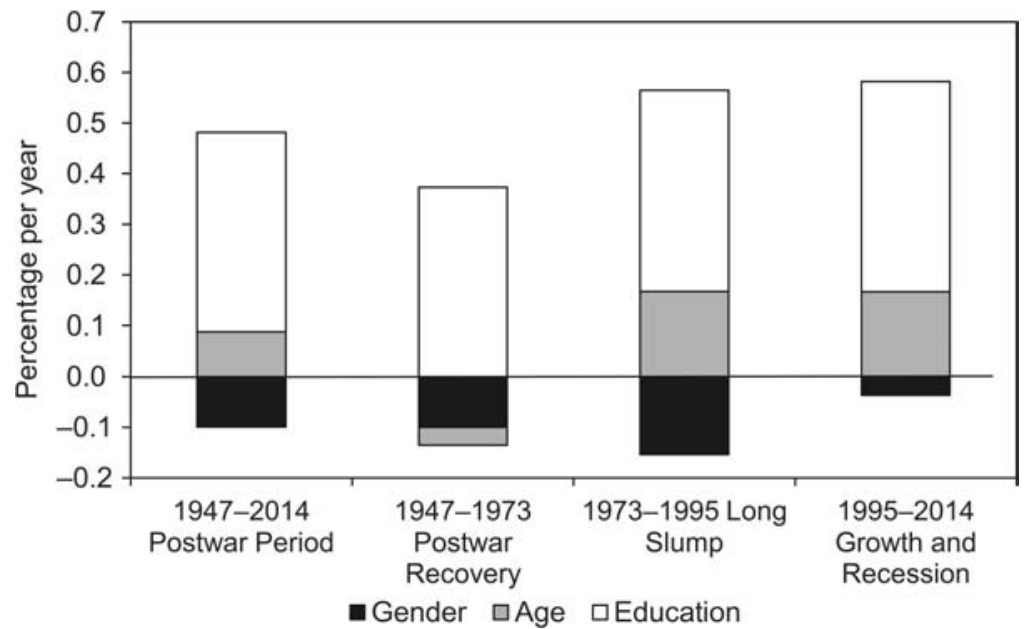

Fig. 1.4 Contribution of education, age, and gender to labor-quality growth

lower-wage workers contributed negatively to labor-quality growth. The rapidly increasing female labor force also contributed negatively, reflecting the lower average labor compensation of female workers. Rising educational attainment generated substantial growth in labor quality. During the Long Slump of 1973-1995, the increase in employment of female workers accelerated and the contribution of the gender composition became more negative. The aging of the labor force contributed positively to labor quality through 


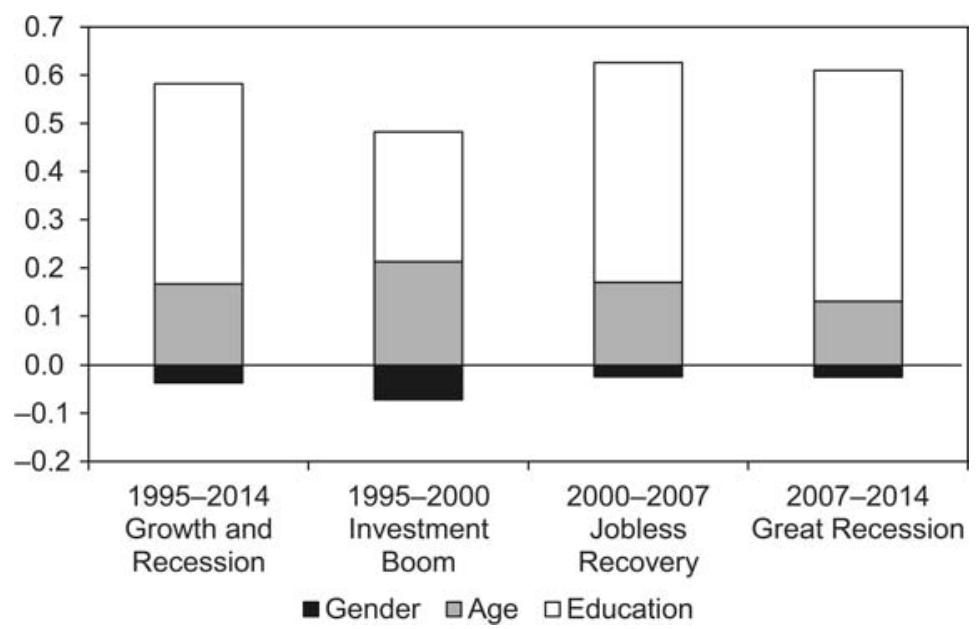

Fig. 1.5 Contribution of education, age, and gender to labor-quality growth, 1995-2014

increased experience, while educational attainment continued to rise and the growth of labor quality became more rapid. The negative impact of increased female employment diminished and labor quality continued to grow as workers gained experience. Considering the period of Growth and Recession in more detail in figure 1.5 , we see that labor quality rose steadily throughout the period. The growth rate declined slightly in 1995-2000, relative to the Long Slump of 1973-1995, as a consequence of a jump in employment by younger and less educated workers. The less negative gender contributions during the Jobless Recovery of 2000-2007 and the Great Recession of 2007-2014 reflect the fact that unemployment rates rose much more sharply for men than for women.

The level of educational attainment of US workers is shown in figure 1.6. In 1947 only a modest proportion of the US workforce had four or more years of college. By 1973 the proportion of college-educated workers had risen dramatically, and this proportion has continued to grow. There was a change in classification in 1992 from years enrolled in school to years of schooling completed. By 2014 almost a third of US workers had completed a BA degree or higher. The fall in the share of workers with lower educational attainment accelerated during the Great Recession.

Figure 1.7 shows that educational attainment of the twenty-five to thirtyfour age group improved substantially during the Postwar Recovery from 1947 to 1973, followed by a pause during the Long Slump of 1973-1995. Gains in educational attainment resumed during the Investment Boom of 1995-2000, and have continued to the present. During the Great Recession, less educated workers had much higher unemployment rates and the average educational attainment rose for workers. 


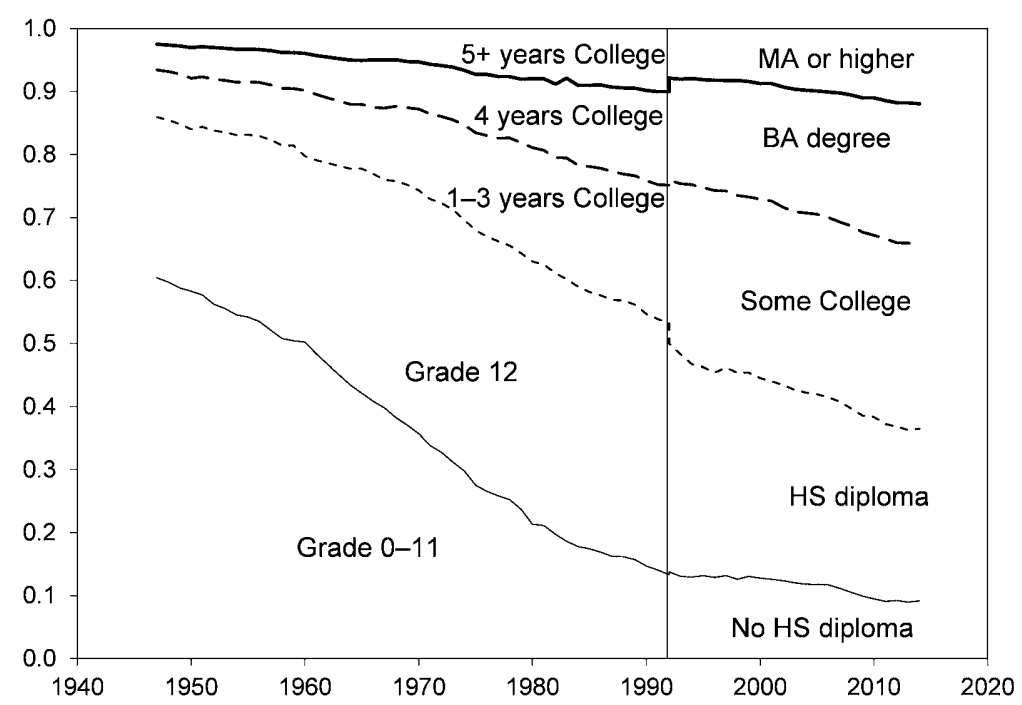

Fig. 1.6 Education attainment of workforce

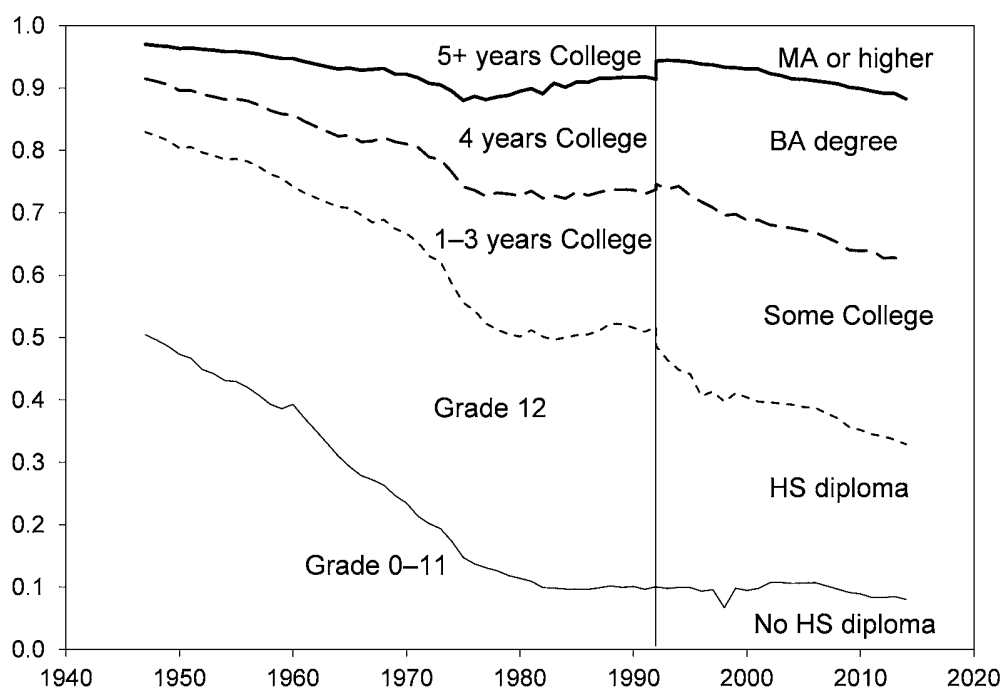

Fig. 1.7 Education attainment of workers age twenty-five to thirty-four

Figure 1.8 gives employment rates of males and females for three age groups - twenty-five to thirty-four, thirty-five to forty-four, and forty-five to fifty-four years old. Better-educated workers are much more likely to be employed for both genders and all three age groups. Male workers with BA degrees have very high employment rates for all years except the recessions. Employment rates for males with high school diplomas are substantially lower. The Investment Boom of 1995-2000 drew in many less educated and 
Male 25-34 years old

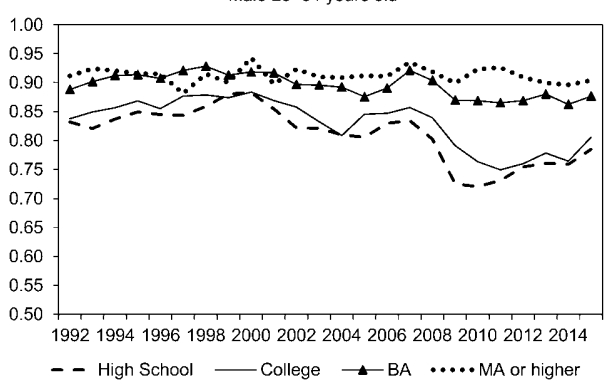

Male 35-44 years old

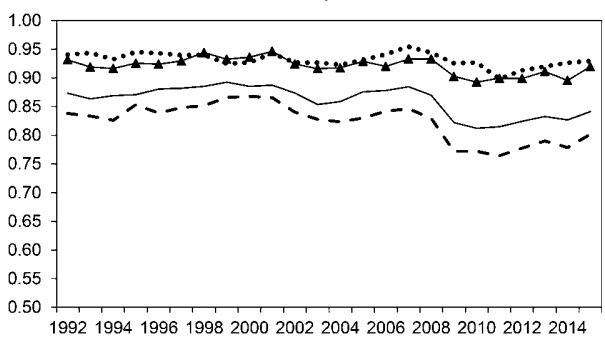

- - High School College $\longrightarrow$ BA .... MA or higher

Male $45-54$ years old

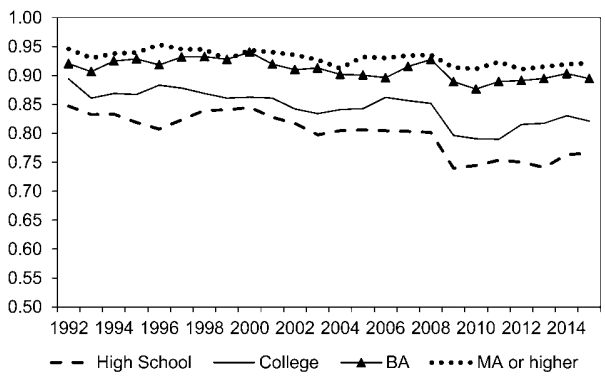

Female $25-34$ years old

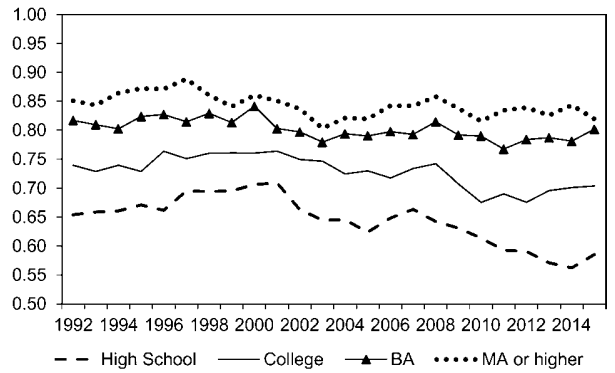

Female $35-44$ years old

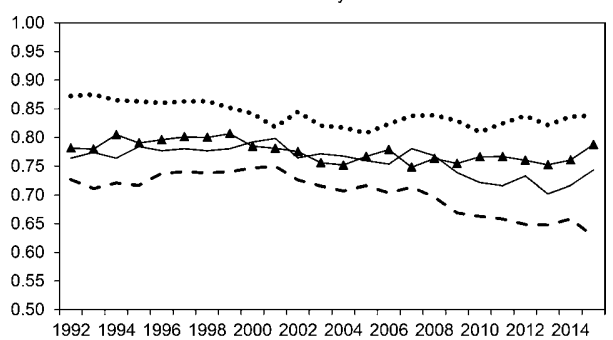

- - High School College —BA ....MA or higher

Female $45-54$ years old

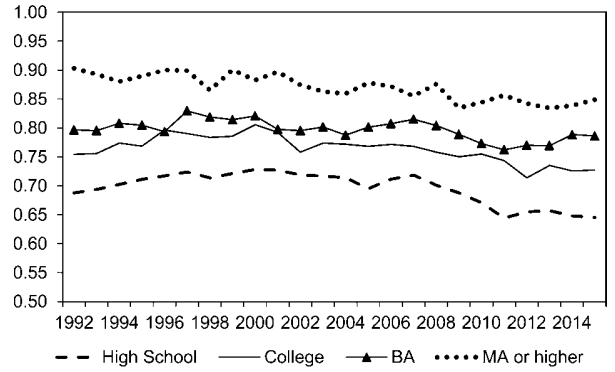

Fig. 1.8 Employment participation rates by gender, age, and education

younger workers, raising their employment rates. The employment rates have fallen since 2000 for the less educated. These rates declined further during the Great Recession.

Although the decline in employment is widely discussed, employment rates by gender, age, and educational attainment, like those presented in figure 1.8, have not been considered until now. A model of employment and unemployment is presented by Kroft et al. (2016). This model has been elaborated by Krueger, Cramer, and Cho (2014).

The modeling of employment and unemployment could be extended to a more detailed breakdown of alternatives to employment for members of the working-age population. These would include disability status and increased participation in welfare programs. Both of these increased as a proportion of 


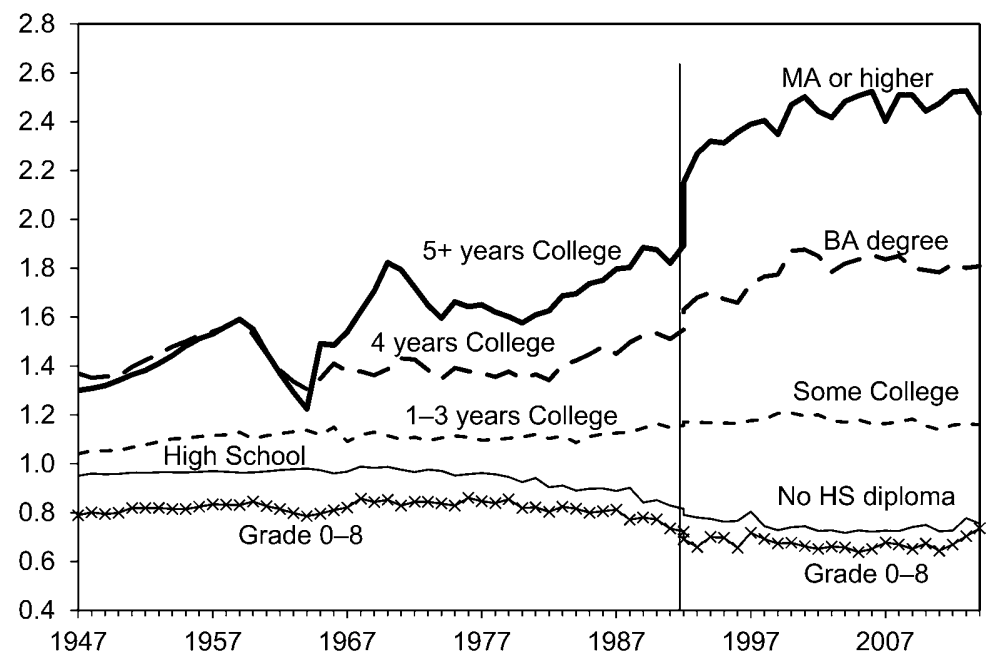

Fig. 1.9 Compensation by education attainment (relative to those with high school diploma)

the working-age population during the Great Recession with relaxation of requirements for eligibility. Employment may have been adversely affected by extended benefit periods for the unemployed, now expired, and lower income requirements for food stamps. ${ }^{5}$

The increase in the "college premium," the difference between wages earned by workers with college degrees and wages of those without degrees, has been widely noted. In figure 1.9 we plot the compensation of workers by educational attainment, relative to those with a high school diploma (four years of high school). We see that the four-year college premium was stable in the 1960s and 1970s, but rose during the 1980s and 1990s. The college premium stalled throughout the first decade of the twenty-first century. The master's-and-higher degree premium rose even faster than the BA premium between 1980 and 2000 and continued to rise through the middle of the first decade of the twenty-first century.

A possible explanation for the rise in relative wages for college-educated workers with a rising share of these workers in the labor force is that their labor services are complementary to the use of information technology. ${ }^{6}$ The most rapid growth of the college premium occurred during the 1995-2000 boom when IT capital made its highest contribution to GDP growth. Our industry-level view of postwar US economic history allows us to consider the role of changing industry composition in determining relative wages.

Table 1.1 gives characteristics of the workforce for each industry for 2010 .

5. The long-term decline in labor force participation for prime-age males is analyzed along these lines by the Council of Economic Advisers (2016).

6. See Goldin and Katz (2008) for more details and historical background. 


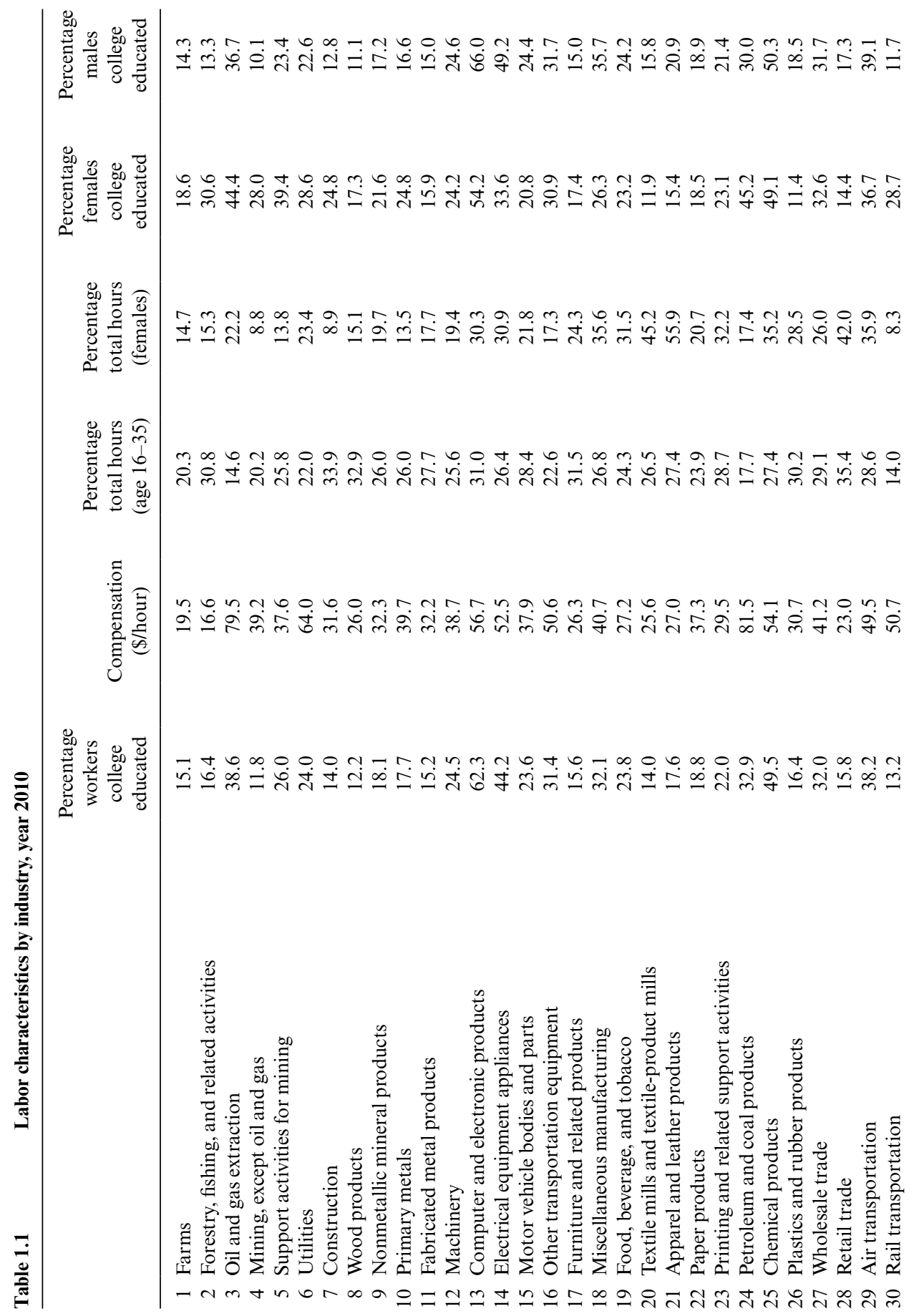




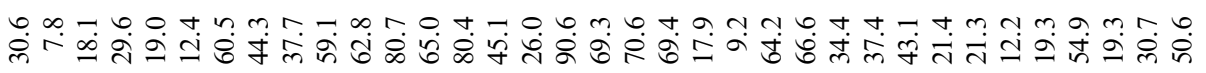

분 m-

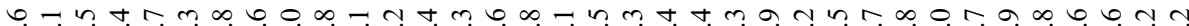

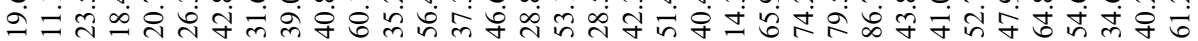

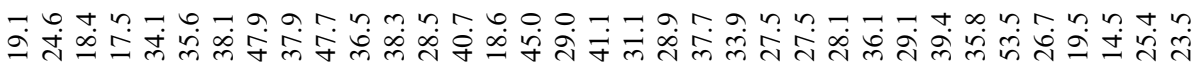

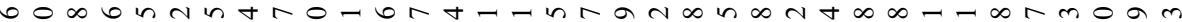

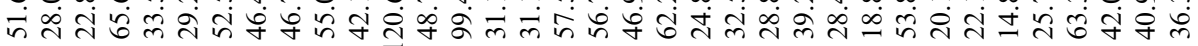

Z

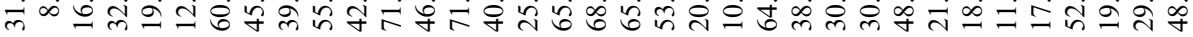

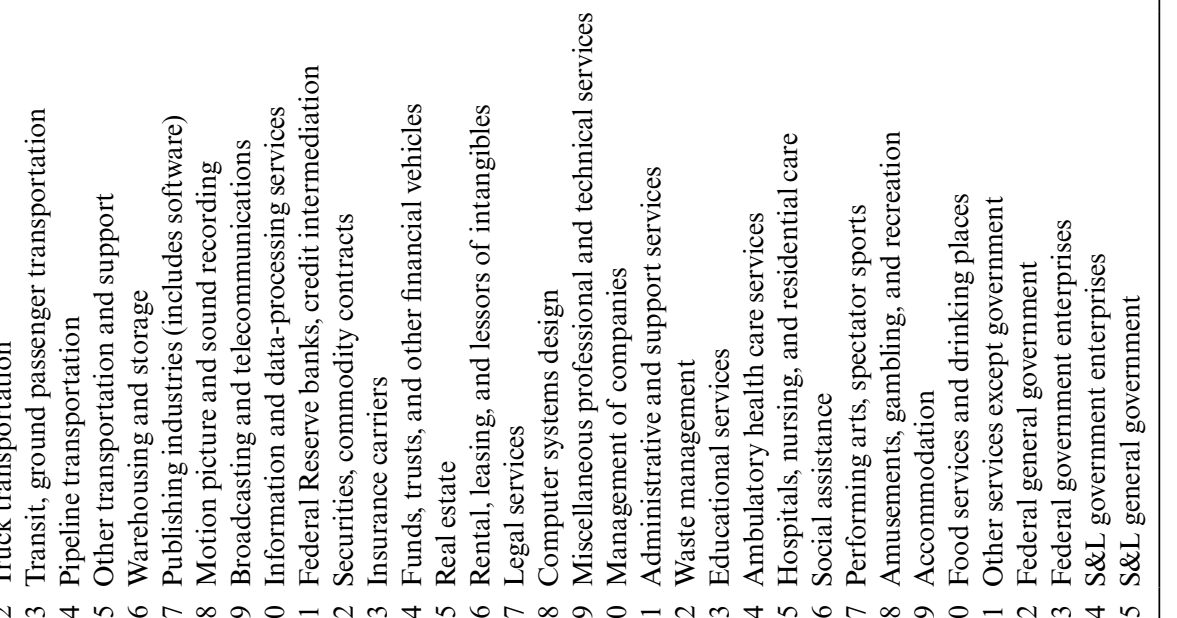

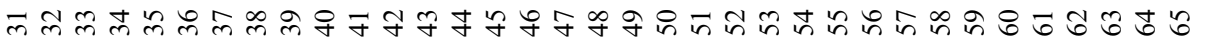




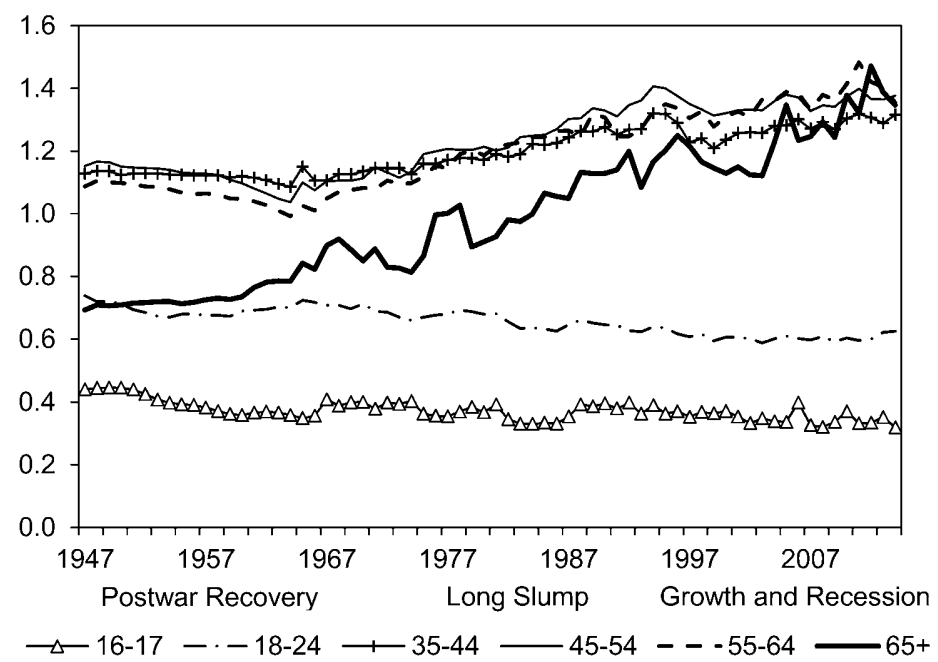

Fig. 1.10 Compensation by age (relative to twenty-five- to thirty-four-year-olds)

The industries with the higher share of college-educated workers include the IT-producing industries - computer and electronic products, publishing (including software), information and data processing, and computer systems design. The industries with higher shares of college-educated workers also include those that use IT products and services intensivelysecurities and commodity contracts, legal services, professional and technical services, and educational services.

After educational attainment, the most important determinant of labor quality is experience, captured by the age of the worker. We have noted that the entry of the baby boomers into the labor force contributed negatively to labor-quality growth during 1947-1973, and that the aging of these workers contributed positively after 1973 . We show the wages of different age groups, relative to the wages of workers age twenty-five to thirty-four, in figure 1.10. The wages of the prime age group, forty-five to fifty-four, rose steadily relative to the young from 1970 to 1994. During the Investment Boom of 1995-2000, the wages of the younger workers surged and the prime-age premium fell.

The wage premium of the thirty-five to forty-four and fifty-five to sixtyfour age groups shows the same pattern as the premium of prime-age workers, first rising relative to the twenty-five- to thirty-four-year-olds, then falling or flattening out during the Investment Boom. The wage premium of the oldest workers is the most volatile, but showed a general upward trend throughout the Postwar Period, 1947-2014. The share of workers age sixtyfive and older has been rising steadily since the mid-1990s, during a period of large swings in the wage premium. The relative wages of the very young, 
eighteen to twenty-four, has been falling steadily since 1970 , reflecting the rising demand for education and experience.

Our new industry-level data set provides detailed information for the period 1947-2014 on the growth of outputs, capital, labor, energy, materials and services inputs, and productivity for the sixty-five industries that make up the US economy. We present new information on educational attainment and the relationship between employment and educational attainment. We also provide detailed information on labor compensation by age and educational attainment. We next consider the application of our new data set to an analysis of the sources of US economic growth. This will be followed by the application of this data set to the projection of the future growth of the US economy.

\subsection{Sources of US Economic Growth}

In analyzing the sources of US economic growth, we first consider the contributions of three major industry groups to the growth of aggregate output. These are the IT-producing industries, the IT-using industries, and non-IT industries, defined more precisely below. We then consider the contributions of these industry groups to aggregate productivity growth, defined as the difference between the growth rates of output and input. Although the IT-producing industries account for a relatively small proportion of the value of US output, they generate a much larger share of productivity growth.

Finally, we consider the growth of capital and labor inputs, as well as productivity growth, as sources of US economic growth. We divide the growth of capital input among IT equipment and software, intellectual property, and all other capital inputs. In order to emphasize the role of the dramatic increases in educational attainment, we divide the growth of labor input between college and noncollege labor inputs. We find that the growth of capital and labor inputs greatly predominates over productivity growth as a source of US economic growth for the Postwar Period, 1947-2014, as well as for the subperiods we consider.

In Information Technology and the American Growth Resurgence, Jorgenson, Ho, and Stiroh (2005) analyze the economic impact of IT at the aggregate level for 1948-2002 and the industry level for 1977-2000. They also provide a concise history of the main technological innovations in information technology during the Postwar Period, beginning with the invention of the transistor in 1947. Jorgenson, Ho, and Samuels (2012) convert the industrial classification to the North American Industry Classification System (NAICS). They update and extend the data to cover seventy industries for the period 1960-2007.

The NAICS industry classification includes the industries identified by Jorgenson, Ho, and Samuels (2012) as IT-producing industries, namely, 


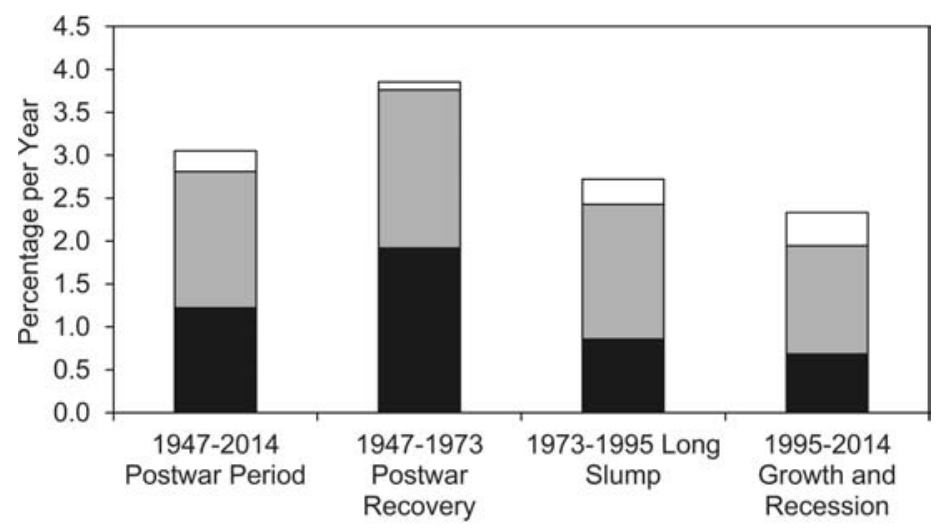

=Non-IT Industries IT-Using Industries aIT-Producing Industries

Fig. 1.11 Contributions of industry groups to value-added growth, 1947-2014

computers, electronic products, and software, and the two IT service industries, information and data processing and computer systems design. Jorgenson, Ho, and Samuels (2012) define an IT intensity index as the ratio of the sum of IT capital input and IT services to the sum of all capital input and IT services. They classify industries as IT-using if the IT intensity index is greater than the median for all US industries that do not produce IT equipment, software, and services. We classify all other industries as non-IT.

Value added in the IT-producing industries during 1947-2014 is only 2.5 percent of the US economy, while value added in the IT-using industries is 47.5 percent with value added in the non-IT industries accounting for the remaining 50 percent. The IT-using industries are mainly in trade and services. Most manufacturing industries are in the non-IT sector. The NAICS industry classification provides much more detail on services and trade, especially the industries that are intensive users of IT. We begin by discussing the results for the IT-producing sectors, now defined to include the two IT service sectors.

Figure 1.11 reveals a steady increase in the share of IT-producing industries in the growth of value added since 1947. This corresponds to a decline in the contribution of the non-IT industries, while the share of IT-using industries remains relatively constant. Figure 1.12 decomposes the growth of value added for the period 1995-2014. The contributions of the IT-producing and IT-using industries peaked during the Investment Boom of 1995-2000 and have declined since then. However, the contribution of the non-IT industries also revived during the Investment Boom and declined substantially during the Jobless Recovery and the Great Recession. Figure 1.13 gives the contributions to value added for the sixty-five individual industries over the 


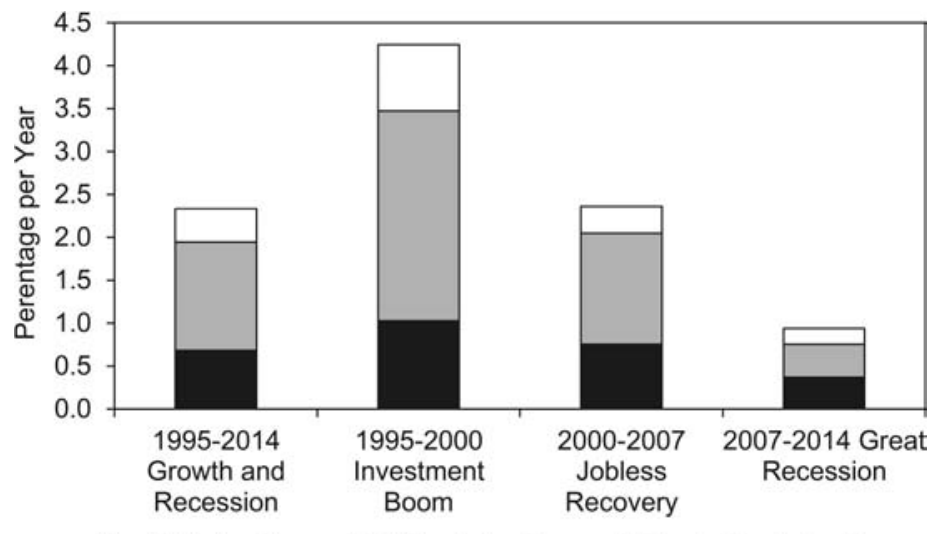

a Non-IT Industries ㅁIT-Using Industries ㅁIT-Producing Industries

Fig. 1.12 Contributions of industry groups to value-added growth, 1995-2014

period 1947-2014. The leading contributors are real estate, wholesale and retail trade, and computer and electronic products.

In order to assess the relative importance of productivity growth at the industry level as a source of US economic growth, we express the growth rate of aggregate productivity as a weighted average of industry productivity growth rates, using the ingenious weighting scheme of Evsey Domar (1961). ${ }^{7}$ The Domar weight is the ratio of the industry's gross output to aggregate value added. The Domar weights for all industries sum to more than one. This reflects the fact that an increase in the rate of growth of the industry's productivity has a direct effect on the industry's output and an indirect effect via the output delivered to other industries as intermediate inputs.

The rate of growth of aggregate productivity also depends on the reallocations of capital and labor inputs among industries. The rate of aggregate productivity growth exceeds the weighted sum of industry productivity growth rates when these reallocations are positive. This occurs when capital and labor inputs are paid different prices in different industries and industries with higher prices have more rapid input growth rates. Aggregate capital and labor inputs then grow more rapidly than weighted averages of industry-capital and labor-input growth rates, therefore the reallocations are positive. When industries with lower prices for inputs grow more rapidly, the reallocations are negative.

Figure 1.14 shows that the contributions of IT-producing, IT-using, and non-IT industries to aggregate productivity growth are similar in magnitude for the period 1947-2014. The non-IT industries contributed substantially

7. The formula is given in Jorgenson, Ho, and Stiroh (2005, equation 8.34). 


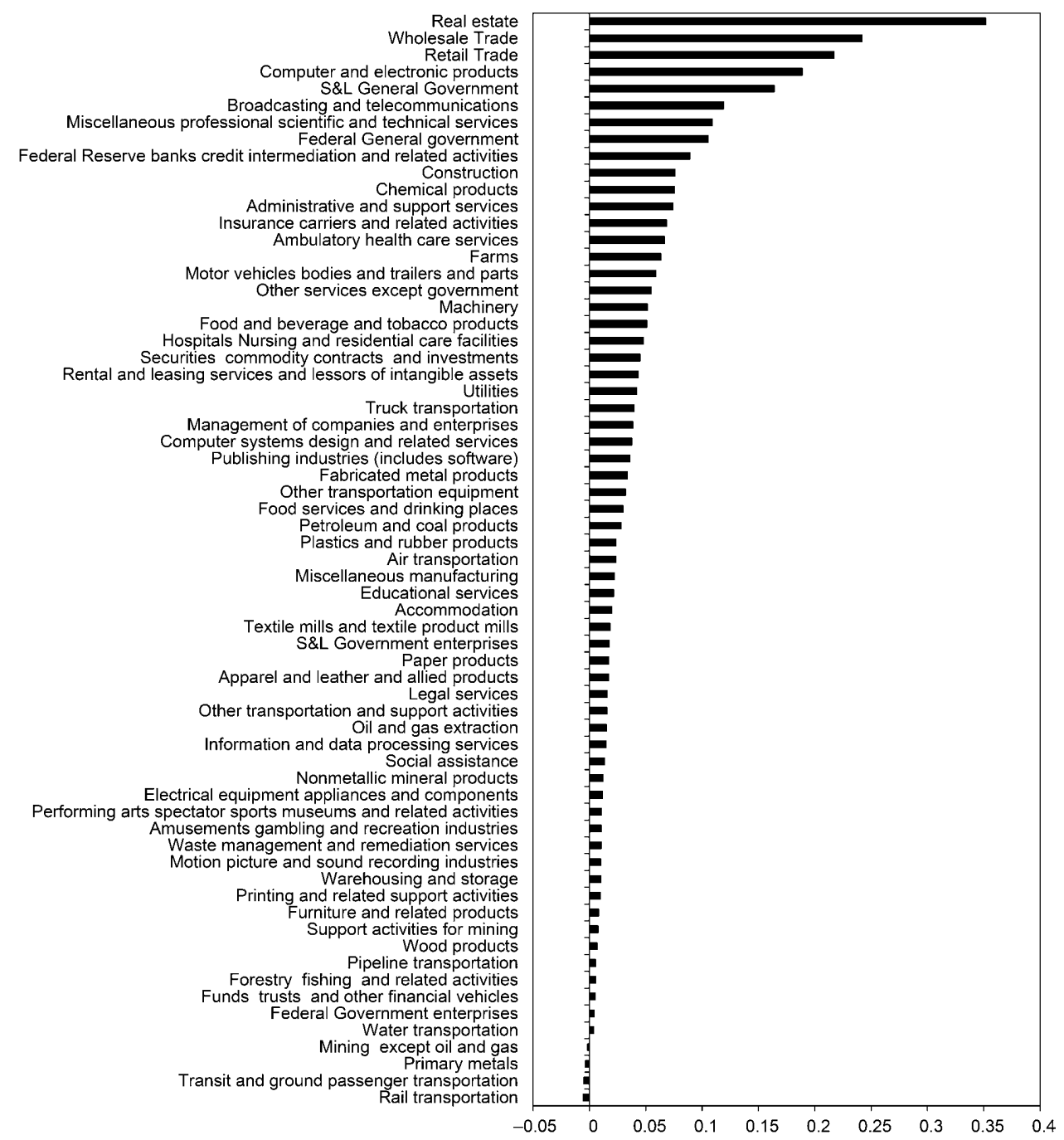

Fig. 1.13 Industry contributions to value added, 1947-2014 (percentage per year)

to productivity growth during the Postwar Recovery, 1947-1973, but this contribution became negative during the Long Slump, 1973-1995. The contribution of IT-producing industries was very small during the Postwar Recovery, but became the predominant source of US productivity growth during the Long Slump, 1973-1995. The contribution of IT-producing industries increased considerably during the period of Growth and Recession, 1995-2014.

The IT-using industries contributed substantially to US productivity 


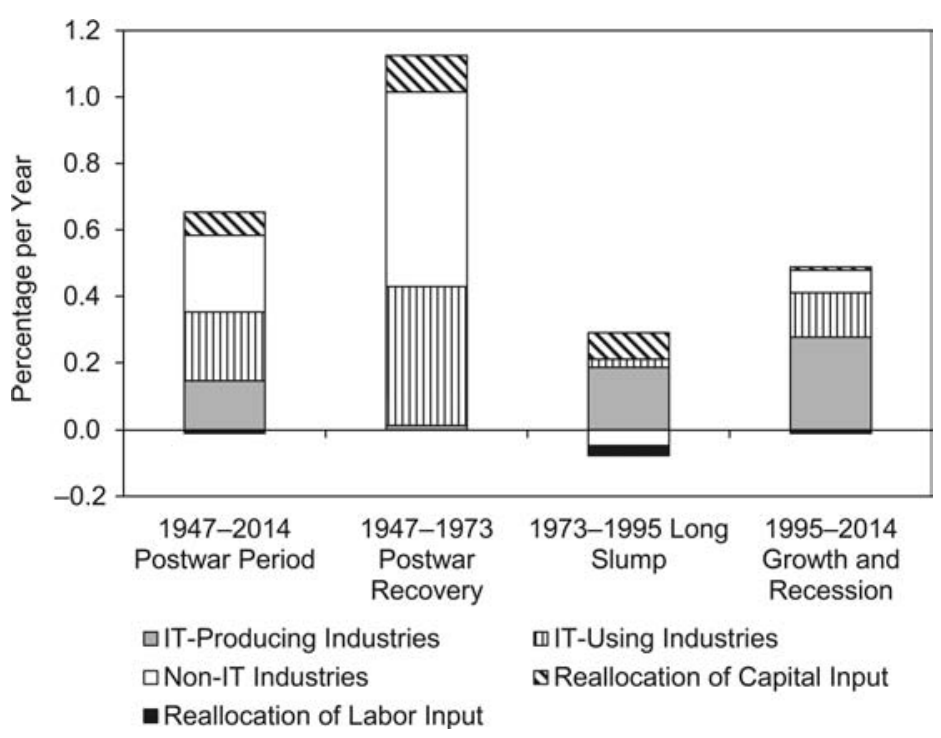

Fig. 1.14 Contribution of industry groups to aggregate productivity growth, 1947-2014

growth during the Postwar Recovery, but this contribution nearly disappeared during the Long Slump, 1973-1995, before reviving after 1995. The reallocation of capital input made a small but positive contribution to productivity growth during the Postwar Period, 1947-2014, and each of the subperiods. The contribution of reallocation of labor input was negligible for the period as a whole. During the Long Slump and the period of Growth and Recession, the contribution of the reallocation of labor input was slightly negative.

Considering the period of Growth and Recession in more detail in figure 1.15, all three industry groups contributed to aggregate productivity growth during the period as a whole. However, the IT-producing industries predominated as a source of productivity growth during the period as a whole and the three subperiods. The contribution of these industries remained substantial during each of the subperiods (1995-2000, 2000-2007, and 2007-2014) despite the sharp contraction of economic activity during the Great Recession of 2007-2009.

The contribution of the IT-using industries was considerable during the Investment Boom of 1995-2000, remained substantial in the Jobless Recovery of 2000-2007, but became slightly negative during the Great Recession of 2007-2014. The non-IT industries contributed positively to productivity growth during the Investment Boom. This contribution rose during the Jobless Recovery and then became negative during the Great Recession.

Figure 1.16 gives the contributions of each of the sixty-five industries to 


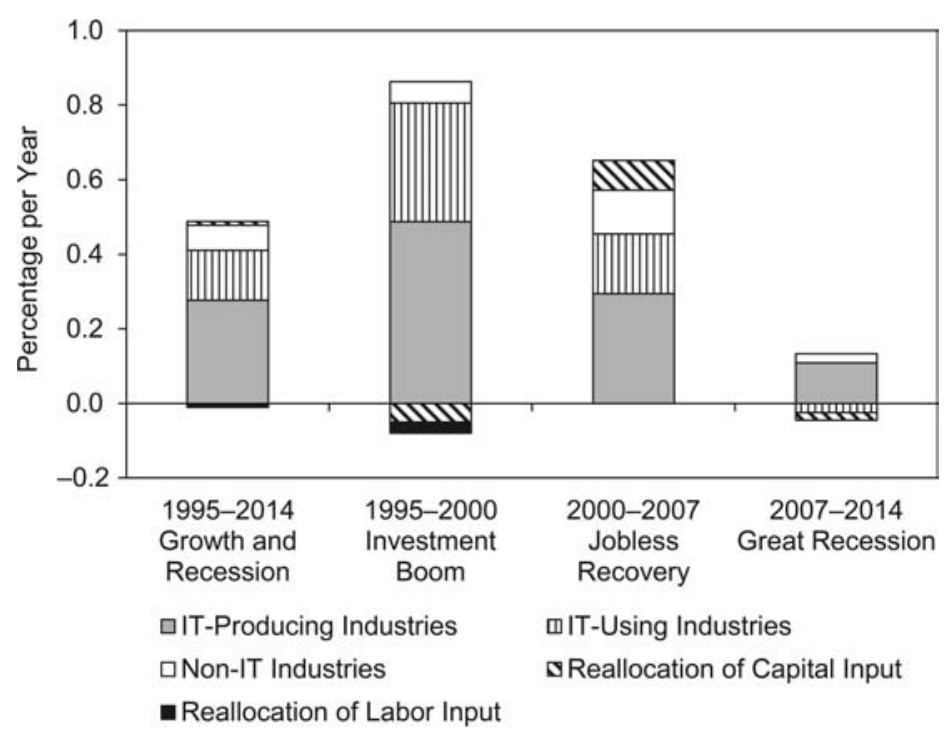

Fig. 1.15 Contribution of industry groups to aggregate productivity growth, 1995-2014

productivity growth for the Postwar Period. Computer and electronic products, wholesale and retail trade, farms, and broadcasting and telecommunications were among the leading contributors to US productivity growth during the Postwar Period. Many industries made negative contributions to aggregate productivity growth. These included nonmarket services such as health care, as well as resource industries affected by depletion, such as oil and gas extraction and mining. Other negative contributions reflect the growth of barriers to resource mobility in product and factor markets due, in some cases, to more stringent government regulations.

Finally, we consider the growth of capital and labor inputs, as well as growth in productivity, as sources of growth of the US economy. The contributions of college-educated and non-college-educated workers to US economic growth are given by the relative shares of these workers in the value of output, multiplied by the growth rates of their labor inputs. Workers with a college degree or higher level of education correspond closely with "knowledge workers" who deal with information. Of course, not every knowledge worker is college educated and not every college graduate is a knowledge worker.

Figure 1.17 shows that contribution of college-educated workers predominated in the growth of labor input during the Postwar Period, 1947-2014. The contribution of non-college-educated workers was greater during the Postwar Recovery, 1947-1973, but declined substantially during the Long Slump of 1973-1995, and almost disappeared during the period 1995-2014 


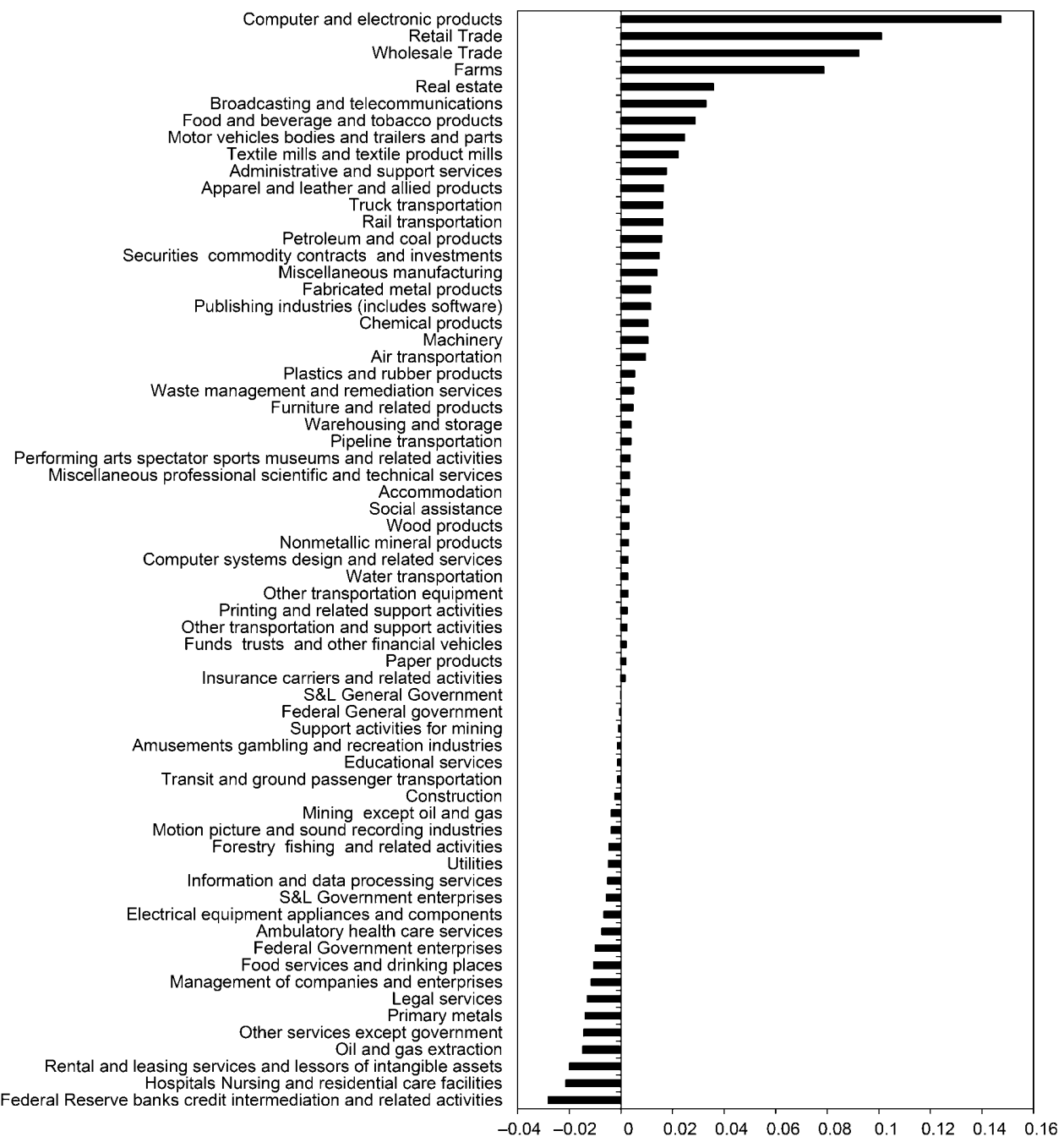

Fig. 1.16 Industry contributions to productivity, 1947-2014 (percentage per year)

of Growth and Recession. The contribution of college-educated workers was the dominant source of growth of labor input during the Long Slump and the period of Growth and Recession.

Capital input was the predominant source of US economic growth for the Postwar Period, 1947-2014, as we show in figure 1.17. Capital input was also predominant during the Postwar Recovery, the Long Slump, and the period of Growth and Recession. Considering the period of Growth and Recession in greater detail, figure 1.18 reveals that the contribution of capital input was about half of US economic growth during the Investment Boom 


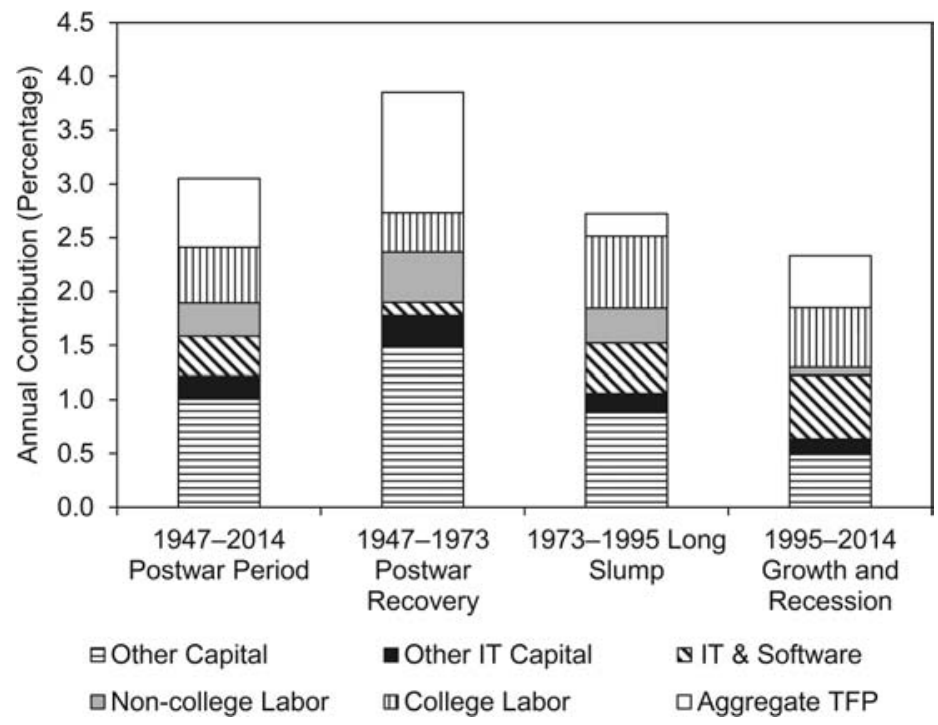

Fig. 1.17 Sources of US economic growth, 1947-2014

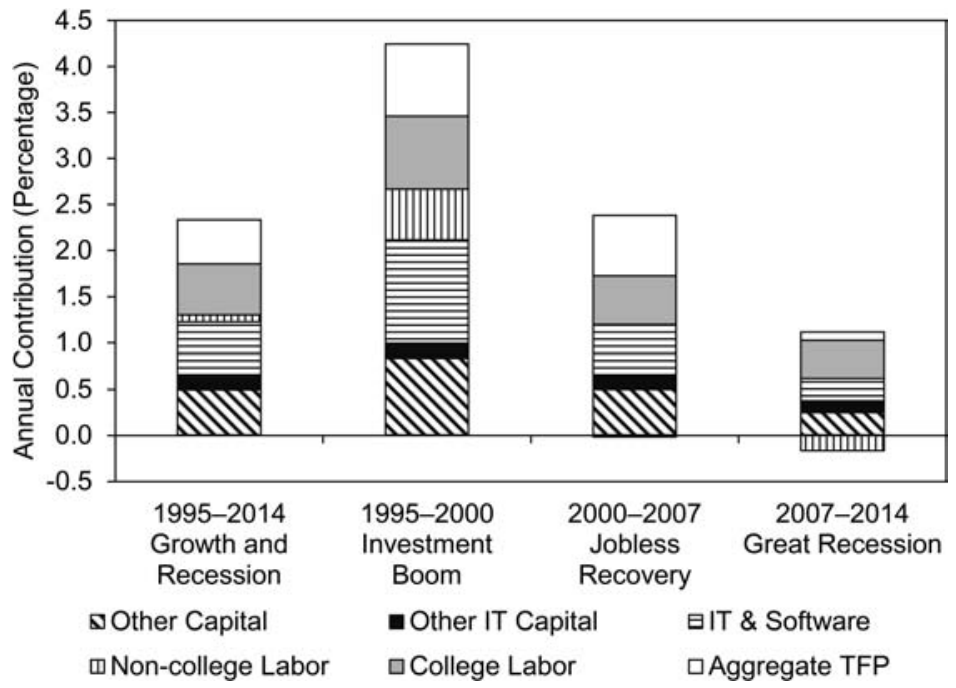

Fig. 1.18 Sources of US economic growth, 1995-2014

and increased in relative importance as the growth rate fell in the Jobless Recovery and again in the Great Recession.

Figure 1.17 also provides greater detail on important changes in the composition of the contribution of capital input. For the Postwar Period as a whole, the contribution of research and development to US economic 
growth was considerably less than the contribution of IT. However, the contributions of other forms of capital input predominated over both. While the contribution of research and development exceeded that of IT during the Postwar Recovery, the contribution of IT grew rapidly during the Long Slump and jumped to nearly half the contribution of capital input during the period of Growth and Recession. By contrast, the contribution of research and development shrank during both periods and became relatively insignificant. Figure 1.18 reveals that the contribution of capital input peaked during the Investment Boom, declined during the Jobless Recovery, and collapsed during the Great Recession, but the relative importance of IT remained the same throughout the period of Growth and Recession.

Figure 1.18 shows that all of the sources of economic growth contributed to the US growth resurgence after 1995, relative to the Long Slump represented in figure 1.17. Both IT and non-IT capital inputs contributed substantially to growth during the Jobless Recovery of 2000-2007, but the contribution of labor input dropped precipitously and the contribution of noncollege workers became slightly negative. The most remarkable feature of the Jobless Recovery was the sustained growth in productivity, indicating an ongoing surge of innovation.

Despite the slowdown of investment during the Great Recession, both IT and non-IT capital inputs continued to contribute substantially to US economic growth during the period 2007-2014. Productivity growth almost disappeared, reflecting a widening gap between actual and potential growth of output. The contribution of college-educated workers remained positive and substantial, while the contribution of noncollege workers became strongly negative. These trends represent increased rates of substitution of capital for labor and college-educated workers for noncollege workers.

We have now identified the sources of the growth of the US economy. The predominant source of US economic growth is the growth of capital and labor inputs. This characterizes the Postwar Period, 1947-2014, and the subperiods we have considered. Second, the growth of capital input is considerably more important than the growth of labor input as a source of US economic growth. Finally, investment in information technology equipment and software is the most important component of the growth of capital input as a source of growth of the US economy.

Productivity growth, while a much less important source of US economic growth than the growth of capital and labor inputs, is essential for sustaining economic growth in the long run. We have seen that productivity growth in the IT-producing industries has been the most important source of US productivity growth during the Postwar Period, 1947-2014. The contribution of the IT-producing industries can be traced to developments in technology that were successfully commercialized after the Postwar Recovery, 1947-1973. 


\subsection{Future US Economic Growth}

Our final objective is to assess the prospects for revival of US economic growth. We present three alternative projections for US economic growth for the period 2014-2024: Base Case, Low Growth, and High Growth. This enables us to quantify the uncertainty in projections of the growth of capital quality and productivity growth. We present the three alternative projections in figures $1.19,1.20$, and 1.21. We compare these projections with historical data for the period 1990-2014.

Figure 1.19 includes three alternative projections of productivity growth for the period 2014-2024. For the Base Case, we set future productivity growth rates for IT-producing, IT-using, and non-IT industries equal to growth rates for the period of Growth and Recession, 1995-2014. The Low Growth projection is based on productivity growth rates for the period 1973-2014, including the Long Slump of 1973-1995. The High Growth projection incorporates productivity growth rates for the recent period, 2000-2014, including the Jobless Recovery of 2000-2007 and the Recession and Recovery of 2007-2014.

We use the following assumptions for all three projections: We set the capital share in value added and the share of reproducible capital in total capital stock equal to the averages for the Postwar Period, 1947-2014. We fix the shares of nominal GDP for IT-producing, IT-using, and non-IT sectors at the averages for the recent period, 2000-2014, to reflect changes in the relative importance of information technology. More details about the projections are provided in the appendix.

We define average labor productivity as output per hour worked. The growth rate of labor productivity is the sum of growth rates of labor quality,

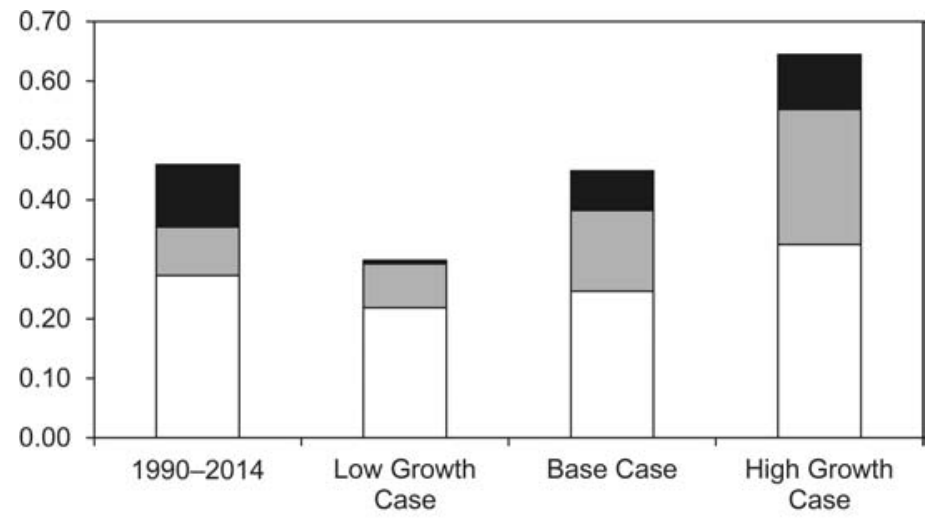

ㅁIT-Producing Industries ㅁIT-Using Industries $\mathbf{m}$ Non-IT Industries

Fig. 1.19 Contribution of industry groups to aggregate productivity, 2014-2024 


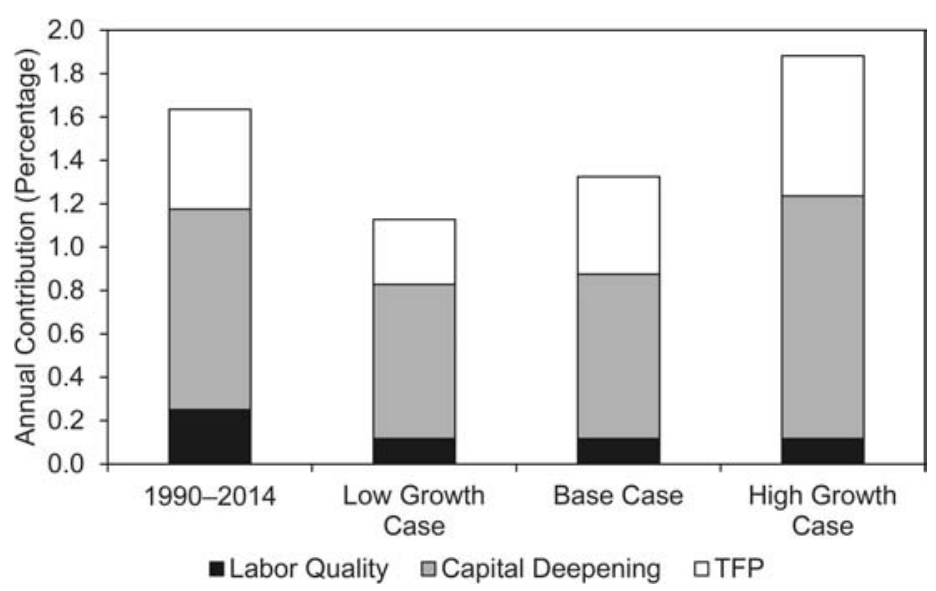

Fig. 1.20 Range of labor productivity projections, 2014-2024

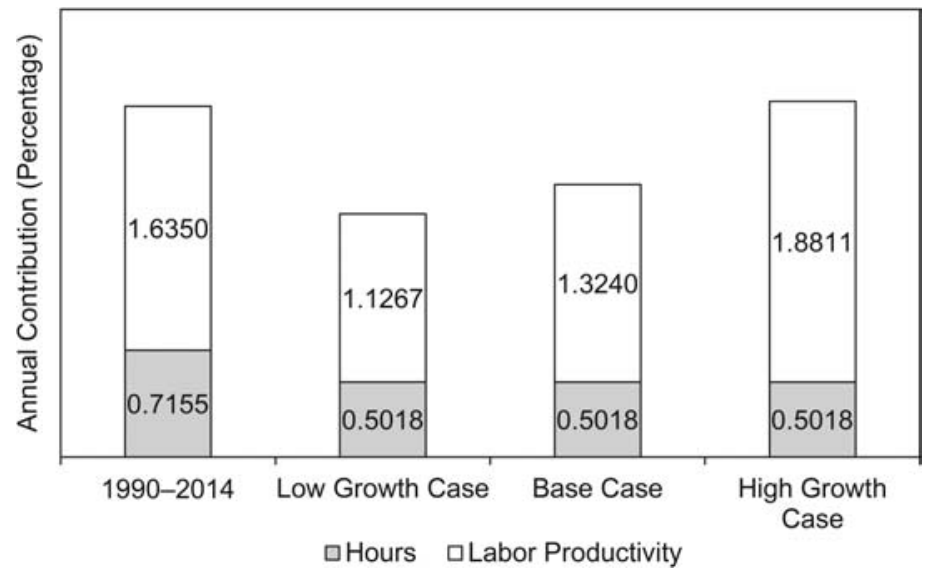

Fig. 1.21 Range of US potential output projections, 2014-2024

capital deepening, and total factor productivity, where capital deepening is defined as capital input per hour worked. We project growth rates of labor productivity and hours worked for the period 2014-2024, which sum to the growth rate of output for the US economy. Figure 1.20 gives the growth rates of labor productivity for the Base Case, Low Growth, and High Growth projections, while figure 1.21 presents the projected growth rates of output.

\subsubsection{Base Case}

Our projections of US economic growth incorporate trends in employment rates by gender, age, and education. For each gender-age-education category we assume that the employment rate remains equal to the rate in 
2014, when the unemployment rate stabilized. We fix weekly hours for each gender-age-education group at the 2014 level, when the US economy reached full employment. Our projections of the growth rates of labor quality for 2014-2024 are considerably below the averages for the period 1990-2014, due to declines in the rates of growth of average educational attainment.

In the Base Case, we assume that the growth rates of capital quality and productivity for the next ten years will equal average growth rates for the period of Growth and Recession, 1995-2014. The Investment Boom of 19952000 combined rapid accumulation of IT capital and robust productivity growth. The Jobless Recovery of 2000-2007 had strong productivity growth, but slower growth of IT capital. The Recession and Recovery of 2007-2014 had weak productivity growth and much slower accumulation of IT capital.

The growth rate of capital quality during the period 1995-2014 that is used in the projection is slightly below the growth rate for the period 19902014. Capital deepening makes the biggest contribution to labor productivity growth, while the growth of productivity in the IT-producing sector will make the second-largest contribution during the period 2014-2024. We project that productivity growth in the IT-using sector during the period 2014-2024 will exceed its contribution during 1990-2014, reflecting more rapid productivity growth and the higher value share of this sector. Finally, total factor productivity (TFP) of the non-IT sector of the economy will contribute relatively little to labor productivity growth, even compared to the period 1990-2014.

Our Base Case projection of labor productivity growth over the next ten years, 2014-2024, is markedly lower than growth during the period 19902014. Our projection of labor-quality growth in the Base Case is also well below growth in 1990-2014. Total hours worked is projected to grow at 0.50 percent per year compared to 0.71 percent during 1990-2014, reflecting the future changes in the age structure and the assumption of fixed annual hours at 2014 levels for each age-gender-education group.

Combining our projected growth rates in hours worked and average labor productivity, we project the GDP growth rate at 1.83 percent per year over the next ten years. This is a substantial decline from the growth rate of 2.35 percent per year during the period 1990-2014. The slower growth in hours worked is reinforced by the slower growth of average labor productivity. We conclude by emphasizing that we do not model the determinants of employment, but rely on extrapolations of trends from the historical data.

\subsubsection{Low Growth Case}

Our first alternative assumption to the Base Case is that capital-quality and productivity growth over the next ten years will equal the averages over 1973-2014, a period that includes the Long Slump and the Recession and Recovery. The period of Recession and Recovery can be subdivided among the IT Boom, the Jobless Recovery, and the Recession and Recovery. By 
including the Long Slump and the Recession and Recovery periods, we dampen the growth rates in this low scenario. Taking averages over 19732014 yields a capital-quality growth rate that is nearly equal to the growth rate for the period 1990-2014.

We project that productivity growth in the IT-producing sector will be only slightly below the rate for 1990-2014. Using the 2000-2014 average share of the IT-producing sector in output, we obtain a substantial contribution of productivity growth from the IT-producing sector to growth of labor productivity. We project that the growth of productivity in the IT-using sector will be almost equal to the contribution for the period 1990-2014. Finally, we project that productivity growth from the non-IT sector will contribute very little to average labor productivity growth, even less than during the period 1990-2014.

In the Low Growth Case, our projected labor productivity growth for the next ten years is below the Base Case projection. Both the Base Case and the Low Growth projections are markedly below the growth of labor productivity during the period 1990-2014. The growth of hours worked in both scenarios is below the growth of hours for the period 1990-2014. Summing the growth rates in hours worked and labor productivity, the Low Growth Case projects output growth at 1.63 percent over the next ten years. This is a marked deceleration from the growth rate of 2.35 percent for the period 1990-2014.

\subsubsection{High Growth Case}

For the High Growth Case we assume that employment rates for each gender-age-education group are the same as in the Base Case for the ten-year period 2014-2024. Hours worked is also projected to grow at 0.50 percent over the next decade as in the Base Case, and the growth rate of labor quality will be substantially lower than during the period 1990-2014. We assume that growth rates of capital quality and productivity for the next ten years will equal their averages over the period 1995-2007. This includes the Investment Boom and the Jobless Growth periods, but excludes the Long Slump and the Great Recession as temporary slowdowns in economic growth. Taking averages over 1995-2007 yields a capital-quality growth rate significantly higher than the growth rate over the period 1990-2014.

In the High Growth Case, productivity growth in the IT-producing sector is more rapid than in the Base Case. This translates into a relatively high contribution of growth in total factor productivity to growth in average labor productivity. The growth of total factor productivity in the IT-using sector is also projected at a higher rate than in the Base Case. Finally, we project that productivity growth in the remainder of the economy will contribute more to labor productivity growth than in the Base Case.

Combining projections of growth in labor productivity and hours worked, the High Growth projection of GDP growth is 2.38 percent per year, only 
slightly above the growth rate of 2.35 percent during the period 1990-2014. Higher growth of productivity and capital quality are offset by lower growth of labor quality and slower capital deepening. It is important to recall that our projections of employment rates differ by demographic group, therefore the rapid growth in hours worked reflects the disparate impacts of the Great Recession on different types of workers.

\subsubsection{Alternative Projections}

Byrne, Oliner, and Sichel (2013) survey contributions to the debate over prospects for future US economic growth since the Great Recession. Cowen (2011) presents a pessimistic outlook in his book, The Great Stagnation: How America Ate All the Low-Hanging Fruit, Got Sick, and Will (Eventually) Feel Better. Cowen (2013) expresses a more sanguine view in his book, Average Is Over: Powering America Beyond the Age of the Great Stagnation. Robert Gordon (2016) analyzes headwinds facing the US economy in his book, The Rise and Fall of American Economic Growth: The US Standard of Living since the Civil War.

Byrne, Oliner, and Sichel (2013) provide detailed evidence on the recent behavior of IT prices. This is based on research at the Federal Reserve Board to provide deflators for the Index of Industrial Production. While the size of transistors has continued to shrink, performance of semiconductor devices has improved less rapidly, severing the close link that had characterized Moore's Law as a description of the development of semiconductor technology. ${ }^{8}$ This view is supported by Pillai (2011) and by computer scientists Hennessey and Patterson (2012). ${ }^{9}$

Gordon's pessimism about the future development of technology in the IT-producing industries is forcefully rebutted by Brynjolfsson and McAfee (2014) in the Second Machine Age: Work, Progress, and Prosperity in a Time of Brilliant Technologies. ${ }^{10}$ Baily, Manyika, and Gupta (2013) summarize an extensive series of studies of the prospects for technology in American industries, including the IT-producing industries, conducted by the McKinsey Global Institute and summarized by Manyika et al. (2011). These studies also present a more optimistic view of future technological developments.

Fernald (2016) presents a number of alternative projections and of US GDP growth and chooses a modal forecast of 1.6 percent per year as the most likely outcome. The Congressional Budget Office (CBO 2016) presents GDP projections for ten to thirty years. The thirty-year projection is 2.1 percent per year. The projections of Fernald and the CBO are compared with our three alternative projections — Low, Base Case, and High — in table 1.2.

8. Moore's Law is discussed by Jorgenson, Ho, and Stiroh (2005, chapter 1).

9. See Hennessey and Patterson (2012, figure 1.16, 46). An excellent journalistic account of the slowdown in the development of Intel microprocessors is presented by John Markoff in the New York Times for September 27, 2015.

10. Brynjolfsson and Gordon have debated the future of information technology on TED. See http://blog.ted.com/2013/02/26/debate-erik-brynjolfsson-and-robert-j-gordon-at-ted2013/. 
Comparison of growth projections (percent per year)

\begin{tabular}{lcllllll}
\hline Source & $\begin{array}{c}\text { Projection } \\
\text { period }\end{array}$ & ALP & Hours & GDP & TFP & $\begin{array}{c}\text { Capital } \\
\text { deepening }\end{array}$ & $\begin{array}{c}\text { Labor } \\
\text { quality }\end{array}$ \\
\hline CBO (2016) & $2015-25$ & 1.6 & 0.5 & 2.1 & $1.4(\mathrm{NFB})$ & & \\
Fernald (2016) & $7-10$ years & 1.06 & 0.55 & 1.6 & & & 0.20 \\
Jorgenson, Ho, and & Low case & 1.13 & 0.50 & 1.63 & 0.30 & 0.71 & 0.21 \\
Samuels (2016) & Base case & 1.32 & 0.50 & 1.83 & 0.45 & 0.76 & 0.21 \\
& High case & 1.88 & 0.50 & 2.38 & 0.64 & 1.12 & 0.21 \\
\hline
\end{tabular}

All three sets of projections are based on the analysis of sources of US economic growth.

The methodology employed by the $\mathrm{CBO}$ is inconsistent with the methodology used in the US National Income and Product Accounts and employed by Fernald, as well as by ourselves. The CBO does not include growth of labor quality in its analysis of the sources of growth. The $\mathrm{CBO}$ projections omit the slowdown in the growth of labor quality due to the leveling of average educational attainment for the US population that we have analyzed. Unfortunately, this has a major impact on the CBO's long-term projections of the federal government budget and, in particular, the CBO's projections of the government deficit, which determines whether the US budget is fiscally sustainable.

The CBO's Extended Baseline scenario, which corresponds to our Base Case projection, assumes a growth rate of total factor productivity of 1.3 percent per year. Under this assumption, the $\mathrm{CBO}$ projects that federal debt held by the public will reach 141 percent of the US GDP in $2046 .{ }^{11}$ The $\mathrm{CBO}$ also presents an alternative projection, based on a growth rate of total factor productivity of 0.8 percent per year. For this projection, federal debt held by the public will reach of 173 percent of the GDP in 2046. In contrast, our Base Case estimate of total factor productivity growth is 0.46 percent per year, outside the range of estimates of productivity growth considered by the CBO. This would raise the Base Case estimate of federal debt held by the public in 2046 to 195 percent of the GDP. A refinement of this estimate would involve adding our estimate of the contribution of labor-quality growth omitted by the CBO of 0.12 percent per year to our Base Case estimate of total factor productivity growth. This would reduce the 2016 estimate of federal debt held by the public to 187 percent of the GDP in 2046.

\subsection{Conclusions}

Our industry-level data set for the Postwar Period shows that the growth of capital and labor inputs, recently through the growth of college-educated

11. Congressional Budget Office (2016, figure 7-3, 83). 
workers and investments in both IT and non-IT capital, explains by far the largest proportion of US economic growth. International productivity comparisons reveal similar patterns for the world economy, its major regions, and leading industrialized, developing, and emerging economies. ${ }^{12}$ Studies for more than forty countries have extended these comparisons to individual industries for the countries included in the World KLEMS Initiative. The results are reported in detail in Jorgenson, Fukao, and Timmer (2016).

Conflicting interpretations of the Great Recession can be evaluated from the perspective of our new data set. We do not share the technological pessimism of Cowen (2011) and Gordon (2016), especially for the IT-producing industries. Careful studies of the development of semiconductor and computer technology show that the accelerated pace of innovation that began in 1995 has reverted to lower, but still substantial, rates of innovation. Productivity growth in the IT-producing industries made a substantial positive contribution to aggregate productivity growth during the Great Recession.

Our findings also contribute to an understanding of the future potential for US economic growth. Our new projections are consistent with the perspective of Jorgenson, Ho, and Stiroh (2008), who showed that the peak growth rates of the Investment Boom of 1995-2000 were not sustainable. However, our projections are similar to those we presented earlier in Jorgenson, Ho, and Samuels (2016). While the low productivity growth of the Great Recession will be transitory, productivity growth is unlikely to return to the high growth rates of the Investment Boom and the Jobless Recovery.

Finally, we conclude that the new findings presented in this chapter have important implications for US economic policy. Maintaining the gradual recovery from the Great Recession will require a revival of investment in IT equipment and software, and non-IT capital as well. Enhancing opportunities for employment is also essential. While this is likely to be most successful for highly educated workers, raising participation rates for the less educated workers and the young will be needed for a revival of US economic growth.

\section{Appendix}

\section{Projections}

We adopt the methodology of Jorgenson, Ho, and Stiroh (2008) to utilize data for the sixty-five industries included in the US National Income and Product Accounts. The growth in aggregate value added $(Y)$ is an index of the growth of capital $(K)$ and labor $(L)$ services and aggregate growth in productivity $(A)$ :

12. See Jorgenson and $\mathrm{Vu}(2017)$. 


$$
\Delta \ln Y=\bar{v}_{K} \Delta \ln K+\bar{v}_{L} \Delta \ln L+\Delta \ln A .
$$

To distinguish between the growth of primary factors and changes in composition, we decompose aggregate capital input into the capital stock $(Z)$ and capital quality $(K Q)$, and labor input into hours $(H)$ and labor quality $(L Q)$. We also decompose the aggregate productivity growth into the contributions from the IT-producing industries, the IT-using industries, and the non-IT industries. The growth of aggregate output becomes

$$
\begin{aligned}
\Delta \ln Y= & \bar{v}_{K} \Delta \ln Z+\bar{v}_{K} \Delta \ln K Q+\bar{v}_{L} \Delta \ln H+\bar{v}_{L} \Delta \ln L Q, \\
& +\bar{u}_{I T P} \Delta \ln A_{I T P}+\bar{u}_{I T U} \Delta \ln A_{I T U}+\bar{u}_{N I T} \Delta \ln A_{N I T}
\end{aligned}
$$

where the $\Delta \ln A_{i}$ 's are productivity growth rates in the IT-producing, ITusing, and non-IT groups, and the $u$ 's are the appropriate weights. Labor productivity, defined as value added per hour worked, is expressed as

$$
\Delta \ln y=\Delta \ln Y-\Delta \ln H .
$$

We recognize the fact that a significant component of capital income goes to land rent. In our projections we assume that land input is fixed, and thus the growth of aggregate capital stock is

$$
\text { (1A.4) } \quad \Delta \ln Z=\bar{\mu}_{R} \Delta \ln Z_{R}+\left(1-\bar{\mu}_{R}\right) \Delta \ln L A N D=\bar{\mu}_{R} \Delta \ln Z_{R},
$$

where $Z_{R}$ is the reproducible capital stock and $\bar{\mu}_{R}$ is the value share of reproducible capital in total capital stock.

We project growth using equation (1A.2), assuming that the growth of reproducible capital is equal to the growth of output, $\Delta \ln Y^{P}=\Delta \ln Z_{R}^{P}$, where the $P$ superscript denotes projected variables. With this assumption, the projected growth rate of average labor productivity is given by

(1A.5) $\Delta \ln y^{P}=\frac{1}{1-\bar{v}_{K} \bar{\mu}_{R}} \times\left[\begin{array}{l}\bar{v}_{K} \Delta \ln K Q-\bar{v}_{K}\left(1-\bar{\mu}_{R}\right) \Delta \ln H+\bar{v}_{L} \Delta \ln L Q \\ +\bar{u}_{I T P} \Delta \ln A_{I T P}+\bar{u}_{I T U} \Delta \ln A_{I T U}+\bar{u}_{N I T} \Delta \ln A_{N I T}\end{array}\right]$.

We emphasize that this is a long-run relationship that removes the transitional dynamics related to capital accumulation.

To employ equation (1A.5), we first project the growth in hours worked and labor quality. We obtain population projections by age, race, and gender from the US Census Bureau ${ }^{13}$ and organize the data to match the classifications in our labor database (eight age groups, two genders). We read the 2010

13. The projections made by the US Census Bureau in 2012 are given on their website (http:// www.census.gov/population/projections/data/national/2012.html). The resident population is projected to be 420 million in 2060 . We make an adjustment to give the total population including Armed Forces overseas. 
Census of Population to construct the educational attainment distribution by age, based on the 1 percent sample of individuals. We use the microdata in the Annual Social and Economic Supplement (ASEC) of the Current Population Survey to extrapolate the educational distribution for all years after 2010 and to interpolate between the 2000 and 2010 Censuses. This establishes the actual trends in educational attainment for the sample period.

Educational attainment derived from the 2010 Census shows little improvement for males compared to the 2000 Census with some age groups showing a smaller fraction with professional degrees. However, the proportion of females with BA degrees is higher in 2010 than 2000. Our next step is to project the educational distribution for each gender-age group. For this purpose we use the historical improvements in educational attainment by these groups shown in figure 1.6.

Educational attainment of workers at the end of our sample period is dominated by the effects of the Great Recession. Less educated workers experienced much higher unemployment rates than those with college degrees and had lower rates of participation. Second, improvement in the share of men with BA or MA or higher degrees between 2000 and 2010 is modest, with some age groups falling behind. The improvement in women's education is more pronounced, especially in the older age groups, but there are also certain age groups of women that regressed.

Given these observations, we assume continuing improvement for all ages. We allow a continuing rise in the share of people in each age group with BAs or MAs, based on the observed educational attainment in 2000 and 2010. The gain in the share with BAs and MAs among men during these ten years was very small, even negative for some age groups. The gain among women is greater, but not uniformly positive for all ages.

We establish a long-run target of maximum educational attainment for $2030 e_{\text {saet }}^{\max }$ by assuming that there will be higher shares of people with BA degrees, MA degrees, professional degrees, or PhD degrees, with offsetting lower shares in the other categories (associate degree, some college, high school diploma, some high school). We impose a target education-age profile that is changing smoothly for two groups of men - those with BA degrees and professional degrees.

For men, we assume that the increase in the share of BAs by 2030 is similar to the change between 2000 and 2010 for those between twenty-four and forty-four years old. Given that the education-age profiles are somewhat erratic, this projection results in a somewhat uneven improvement by age. For the professional degree target for men, we assume that the future increase in the share is similar to the improvement between 2000 and 2010 for ages twenty-seven to thirty-seven. We apply similar rules for the associate degrees, $\mathrm{BA}, \mathrm{MA}$, and $\mathrm{PhD}$ categories. We then apply a reverse rule that lowers the share of those with elementary school, some high school without diploma, and high school diploma. 
We apply a similar procedure for women. We impose a smooth increase for the share of women with MA degrees that covers both the 2000 and 2010 lines. We also assume higher shares for professional degrees and $\mathrm{PhDs}$ and offset this with shares of BAs and associate degrees that are very close to the 2010 values, and lower shares for high school diploma and lower categories.

After establishing the $e_{\text {saet }}^{\max }$ target for 2030, we interpolate the 2014-2030 projected matrices linearly using the actual 2014 values and the target:

$$
e_{\text {saet }}^{p}=\omega_{t} e_{\text {saet }}^{2012}+\left(1-\omega_{t}\right) e_{\text {saet }}^{\max } t=2014, \ldots, 2030 .
$$

We apply this projected improvement to those age sixty and younger, and allow those age sixty-one and older to carry their educational attainment as they age:

$$
\begin{aligned}
& e_{\text {saet }}=e_{\text {saet }}^{p} a=0, \ldots, 60 \\
& e_{\text {saet }}=e_{s, a-1, e, t-1}^{p} a=61, \ldots, 90+.
\end{aligned}
$$

Given that those age $a(>60)$ in 2014 have higher educational attainment than those age $a-1$ in 2014, this assumption generates a rising level of attainment in the population.

We assume that the educational attainment for men age thirty-nine or younger will be the same as the last year of the sample period; that is, a man who becomes twenty-two years old in 2024 will have the same chance of having a BA degree as a twenty-two-year-old man in 2014. For women, this cutoff age is set at thirty-three. For men older than thirty-nine years, and women older than thirty-three, we assume that they carry their education attainment with them as they age. For example, the educational distribution of fifty-year-olds in 2024 is the same as that of forty-year-olds in 2014, assuming that death rates are independent of educational attainment. Since a fifty-year-old in 2024 has a slightly higher attainment than a fiftyone-year-old in 2022, these assumptions result in a smooth improvement in educational attainment that is consistent with the observed profile in the 2010 Census.

After projecting the population matrix by gender, age, and education for each year, our next step is to project the hours-worked matrices by these characteristics. We use the weekly hours, weeks per year, and compensation matrices in 2014 described in Jorgenson, Ho, and Samuels (2016). We assume there are no further changes in the annual hours worked and relative wages for each age-gender-education cell. We calculate the effective labor input in the projection period by multiplying the 2014 hours per year by the projected population in each cell and weighting the hours per year by the 2014 compensation matrix. The ratio of labor input to hours worked is our labor-quality index.

The growth rate of capital input is a weighted average of the stocks of various assets weighted by their shares of capital income. The ratio of total 
capital input to the total stock is the capital-quality index that rises as the composition of the stock moves toward short-lived assets with high rental costs. The growth of capital quality during the period 1995-2000 was clearly unsustainable. For our Base Case projection we assume that capital quality grows at the average rate observed for 1995-2014. For the High Growth Case we use the rate for 1995-2007. Finally, we use the rate for 1990-2014 for the Low Growth Case.

\section{References}

Aaronson, Daniel, Loujia Hu, Arian Seifoddini, and Daniel Sullivan. 2014. "Declining Labor Force Participation and Its Implications for Unemployment and Employment Growth." Federal Reserve Bank of Chicago Economic Perspectives 38 (4): 11-138.

Aaronson, Stephanie, Tomaz Cajner, Bruce Fallick, Felix Galbis-Reig, Christopher Smith, and William Wascher. 2014. "Labor Force Participation: Recent Developments and Future Prospects." Brookings Papers on Economic Activity Fall: 197-255.

Baily, Martin, James Manyika, and Shalabh Gupta. 2013. "U.S. Productivity Growth: An Optimistic Perspective." International Productivity Monitor 25:3-12.

Brynjolfsson, Erik, and Andrew McAfee. 2014. The Second Machine Age: Work, Progress, and Prosperity in a Time of Brilliant Technologies. New York: W. W. Norton.

Byrne, David, Steven Oliner, and Dan Sichel. 2013. "Is the Information Technology Revolution Over?" International Productivity Monitor 25:20-36.

Congressional Budget Office (CBO). 2016. "The 2016 Long-Term Budget Outlook." Washington, DC, Congressional Budget Office, July.

Council of Economic Advisers. 2016. "The Long-Term Decline in Prime-Age Male Labor Force Participation." Washington, DC, Executive Office of the President.

Cowen, Tyler. 2011. The Great Stagnation: How America Ate All the Low-Hanging Fruit, Got Sick, and Will (Eventually) Feel Better. New York: Dutton.

. 2013. Average Is Over: Powering America beyond the Age of the Great Stagnation. New York: Dutton.

Domar, Evsey. 1961. "On the Measurement of Technological Change." Economic Journal 71 (284): 709-29.

Fernald, John. 2014. "Productivity and Potential Output: Before, during, and after the Great Recession." Working paper, Federal Reserve Bank of San Francisco, June.

2016. "Re-assessing Longer-Run U.S. Economic Growth: How Low?" Working Paper no. 2016-18, Federal Reserve Bank of San Francisco, August. https://www.frbsf.org/economic-research/files/wp2016-18.pdf.

Goldin, Claudia, and Lawrence F. Katz. 2008. The Race between Education and Technology. Cambridge, MA: Harvard University Press.

Gordon, Robert. 2016. The Rise and Fall of American Economic Growth: The US Standard of Living Since the Civil War. Princeton, NJ: Princeton University Press.

Harper, Michael, Brent Moulton, Steven Rosenthal, and David B. Wasshausen. 2009. "Integrated GDP-Productivity Accounts." American Economic Review 99 (2): 74-79. 
Hennessey, John L., and David A. Patterson. 2012. Computer Organization and Design, 4th ed. Waltham, MA: Morgan Kaufmann.

Jorgenson, Dale W. 1963. "Capital Theory and Investment Behavior." American Economic Review 53 (2): 247-59.

2009. The Economics of Productivity. Northampton, MA: Edward Elgar.

Jorgenson, Dale W., Kyoji Fukao, and Marcel P. Timmer, eds. 2016. The World Economy: Growth or Stagnation? Cambridge: Cambridge University Press.

Jorgenson, Dale W., Frank M. Gollop, and Barbara M. Fraumeni. 1987. Productivity and U.S. Economic Growth. Cambridge, MA: Harvard University Press.

Jorgenson, Dale W., Mun S. Ho, and Jon Samuels. 2012. "Information Technology and U.S. Productivity Growth." In Industrial Productivity in Europe, edited by Matilde Mas and Robert Stehrer, 34-65. Northampton, MA: Edward Elgar.

- 2016. "U.S. Economic Growth—Retrospect and Prospect: Lessons from a Prototype Industry-Level Production Account for the U.S." In The World Economy: Growth or Stagnation?, edited by Dale W. Jorgenson, Kyoji Fukao, and Marcel P. Timmer, 34-69. Cambridge: Cambridge University Press.

Jorgenson, Dale W., Mun S. Ho, and Kevin J. Stiroh. 2005. Information Technology and the American Growth Resurgence. Cambridge, MA: MIT Press. 2008. "A Retrospective Look at the U.S. Productivity Growth Resurgence." Journal of Economic Perspectives 22 (1): 3-24.

Jorgenson, Dale W., and Paul Schreyer. 2013. "Industry-Level Productivity Measurement and the 2008 System of National Accounts." Review of Income and Wealth 58 (4): $185-211$.

Jorgenson, Dale W., and Khuong M. Vu. 2017. "The Outlook for Advanced Economies." Journal of Policy Modeling 39 (2): 660-72.

Kim, Donald D., Erich H. Strassner, and David B. Wasshausen. 2014. "Industry Economic Accounts: Results of the Comprehensive Revision Revised Statistics for 1997-2012." Survey of Current Business 94 (2): 1-18.

Kroft, Kory, Fabian Lange, Matthew J. Notowidigdo, and Lawrence F. Katz. 2016. "Long-Term Unemployment and the Great Recession: The Role of Composition, Duration Dependence, and Non-participation." Journal of Labor Economics 34 (S1): S7-54.

Krueger, Alan B., Judd Cramer, and David Cho. 2014. "Are the Long-Term Unemployed on the Margins of the Labor Market?" Brookings Economic Papers Spring: 229-300.

Kuznets, Simon. 1971. Economic Growth of Nations: Total Output and Production Structure. Cambridge, MA: Harvard University Press.

Lyndaker, Amanda S., Thomas Howells III, Erich H. Strassner, and David B. Wasshausen. 2016. "Integrated Input-Output and GDP by Industry Accounts, 19471996." Survey of Current Business 96 (2): 1-9.

Manyika, James, David Hunt, Scott Nyquest, Jaana Remes, Vikrram Malhotra, Lenny Mendonca, Byron August, and Samantha Test. 2011. Growth and Renewal in the United States. Washington, DC: McKinsey Global Institute.

Markoff, John. 2015. "Smaller, Faster, Cheaper, Over: The Future of Computer Chips.” New York Times, Sept. 26. http://www.nytimes.com/2015/09/27/technology /smaller-faster-cheaper-over-the-future-of-computer-chips.html.

Mayerhauser, Nicole M., and Erich H. Strassner. 2010. "Preview of the Comprehensive Revision of the Annual Industry Accounts: Changes in Definitions, Classification, and Statistical Methods." Survey of Current Business 90 (3): 21-34.

McCulla, Stephanie H., Alyssa E. Holdren, and Shelly Smith. 2013. "Improved Estimates of the National Income and Product Accounts: Results of the 2013 Comprehensive Revision." Survey of Current Business 93 (9): 14-45. 
Organisation for Economic Co-operation and Development. (OECD). 2001. Statistical Working Party of the OECD Industry Committee. Paris: Organisation for Economic Co-operation and Development.

Pillai, Unni. 2011. "Technological Progress in the Microprocessor Industry." Survey of Current Business 91 (2): 13-16.

Rosenthal, Steven, Matthew Russell, Jon D. Samuels, Erich H. Strassner, and Lisa Usher. 2016. "BEA/BLS Industry-Level Production Account for the U.S.: Integrated Sources of Growth, Intangible Capital, and the U.S. Economy." In The World Economy: Growth or Stagnation?, edited by Dale W. Jorgenson, Kyoji Fukao, and Marcel P. Timmer, 377-428. Cambridge: Cambridge University Press.

Schreyer, Paul. 2001. OECD Manual: Measuring Productivity: Measurement of Aggregate and Industry-Level Productivity Growth. Paris: Organisation for Economic Co-operation and Development.

-2009. OECD Manual: Measuring Capital. Paris: Organisation for Economic Co-operation and Development.

Solow, Robert M. 1957. "Technical Change and the Aggregate Production Function." Review of Economics and Statistics 39 (3): 312-20.

United Nations, Commission of the European Communities, International Monetary Fund, Organisation for Economic Co-operation and Development, and World Bank. 2009. System of National Accounts 2008. New York, United Nations. http://unstats.un.org/unsd/nationalaccount/sna2008.asp. 